\title{
Working
}

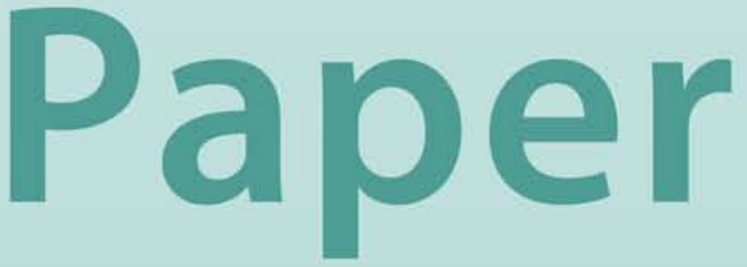


Riding the Roller Coaster: Fiscal Policies of Nonrenewable Resource Exporters in Latin America and the Caribbean

Mauricio Villafuerte, Pablo Lopez-Murphy, Rolando Ossowski 


\title{
IMF Working Paper
}

Fiscal Affairs Department

\section{Riding the Roller Coaster: Fiscal Policies of Nonrenewable Resource Exporters in Latin America and the Caribbean}

\author{
Prepared by Mauricio Villafuerte, Pablo Lopez-Murphy, and Rolando Ossowski ${ }^{1}$
}

Authorized for distribution by Paolo Mauro

November 2010

\section{This Working Paper should not be reported as representing the views of the IMF.}

The views expressed in this Working Paper are those of the author(s) and do not necessarily represent those of the IMF or IMF policy. Working Papers describe research in progress by the author(s) and are published to elicit comments and to further debate.

\begin{abstract}
This paper analyzes recent fiscal policies of nonrenewable resource exporting countries in Latin America and the Caribbean in the context of sharp swings in resource prices. Fiscal policies were predominantly procyclical during the boom period 2003-08 but to significantly differing degrees within the sample. Countries that pursued more conservative fiscal policies during the boom were then able to implement countercyclical fiscal policies during the downturn; moreover, they reduced or maintained their fiscal vulnerability to resource shocks, while their long-term fiscal sustainability positions improved or were broadly unchanged. However, these dimensions of fiscal policy did not seem to be linked to fiscal rules or resource funds, as countries with such institutions displayed a broad range of fiscal responses to the recent cycle.
\end{abstract}

JEL Classification Numbers:E02, E62, H11, H50, H60, H61, H62, O13, Q33

Keywords: Oil producing countries, fiscal policy, fiscal rules, oil funds

Authors’ E-Mail Addresses: mvillafuerte@imf.org; plopezmurphy@imf.org; rossowski@hotmail.com

\footnotetext{
${ }^{1}$ This paper was prepared for the Conference on Fiscal Policy and Macroeconomic Performance organized by the Central Bank of Chile on October 21-22, 2010. We gratefully acknowledge useful comments by Lennart Erickson, Enrique Flores, Javier García-Cicco, Mark Horton, Nicolás Magud, Paolo Mauro, Hunter Monroe, and Teresa TerMinassian. Mauricio Villafuerte and Pablo Lopez-Murphy are staff members of the Fiscal Affairs Department. Rolando Ossowski is a former staff member of the International Monetary Fund. The views expressed herein are those of the authors and should not be attributed to the IMF, its Executive Board, or its management.
} 


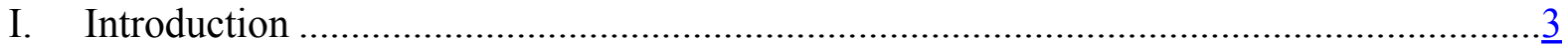

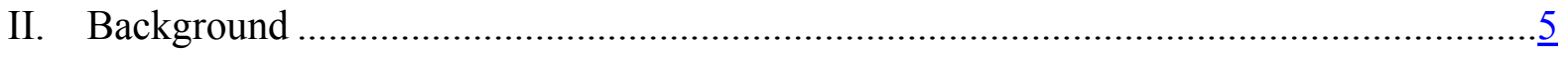

III. Has Fiscal Policy Been Procyclical During the Recent Cycle? ...................................... $\underline{8}$

IV. Short-Term Fiscal Vulnerability to Resource Price Shocks .......................................15

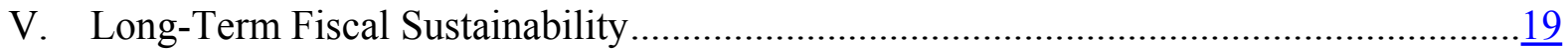

VI. Fiscal Rules and Resource Funds During the Cycle ...............................................23

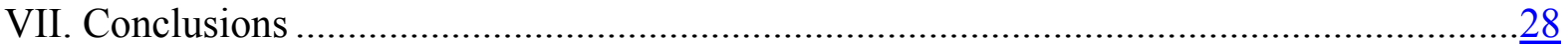

Tables

1. Resource Sector Size and Revenue ....................................................................

2. Fiscal Impulses and Nonresource Output Gaps ..................................................... $\frac{15}{17}$

3. Fiscal Impact of a 15 Percent Fall in Resource Prices................................................ $\frac{17}{18}$

4. Evolution of Fiscal Vulnerability Indicators...................................................................18

Figures

1. Selected Nonrenewable Resource Prices in Real Terms ............................................. 5

2. Oil Price Changes in Real Terms and Global Economic Growth.......................................

3. Growth Rates of Fiscal Revenue in Real Terms ............................................................ $\frac{8}{9}$

4. Changes in Primary Balances ........................................................................................ $\frac{9}{9}$

5. Changes in Nonresource Primary Balances ............................................................... 11

6. NRECs: Fiscal Impulses and Nonresource Output Gaps, 2003-08 …............................13

7. NRECs: Fiscal Impulses and Nonresource Output Gaps, 2009.....................................14

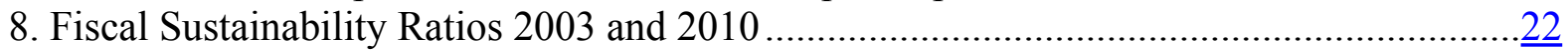

Appendices

1. Fiscal Rules and Resource Funds in LAC Nonrenewable Resource Exporting Countries.. $\underline{34}$

2. Subsidies on Fuel Products and the Fiscal Stance ...................................................

3. What Underlies the Evolution of Nonresource Primary Balances? ................................ 43

4. Calculation of a Long-Term Fiscal Benchmark: An Example ...................................... 45

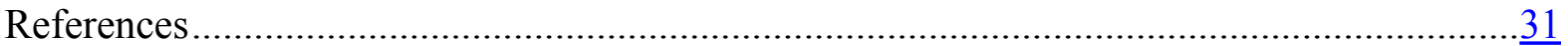




\section{INTRODUCTION}

In the last decade, the prices of nonrenewable resources that constitute a critical source of fiscal revenue in many Latin American and Caribbean (LAC) countries recorded sharp swings correlated with economic growth developments in the world and in the region.

Against this background, the present paper analyzes the fiscal policies of nonrenewable resource exporting countries (NRECs) in LAC during the economic and resource price cycle of the last decade. The analysis focuses on two periods: the boom years, 2003-08; and the more recent period, characterized by the global financial crisis and the receding of resource prices. It examines the role of fiscal policy vis-à-vis fluctuations in economic activity; the evolution of short-term fiscal vulnerability to resource price shocks and long-term fiscal sustainability; and the role played by fiscal rules and resource funds in determining these aspects of fiscal policy. The countries covered in the study are Bolivia, Chile, Ecuador, Mexico, Peru, Trinidad and Tobago, and Venezuela.

The paper starts by presenting background information on recent trends in nonrenewable resource prices and the relevance of nonrenewable resource revenues in the NRECs covered in the study (Section II). It then proceeds to address four sets of questions:

- What were the countries' fiscal policy responses to the recent economic and resource price cycle (Section III)? How expansionary or contractionary were fiscal policies in the boom and the downturn in LAC NRECs? To what extent were these policies procyclical or countercyclical? Is there a relationship between the degree of procyclicality of fiscal policies during the boom and during the slump? How do policies compare to NRECs in other regions?

Several cross-country studies have analyzed the evolution of the fiscal stance in LAC countries in the recent past. ${ }^{2}$ In an early study assessing the fiscal stance in a sample of nine countries during 1981-2004 and linking it to the economic cycle, Alberola and Montero (2006) found that fiscal policy had been procyclical during that period. Izquierdo and Talvi (2008) focused on the seven largest Latin American countries during 2003-07 and concluded that fiscal policy had been expansionary. In contrast, Vladkova-Hollar and Zettelmeyer (2008), using a different methodology, found that fiscal policy had been contractionary in most LAC countries during the same period. Di Bella (2009) explored the fiscal responses of LAC countries to the 2009 downturn and concluded that countries with more prudent fiscal policies during the upswing were able to implement more expansionary fiscal policies during the downturn. Daude, Melguizo, and Neut (2010) found that, although fiscal policies in LAC countries during the last two decades had been procyclical, sustainability had recently improved.

In this paper the analysis of the cyclical stance of fiscal policies takes into account explicitly the special characteristics of revenues arising from nonrenewable resources. It proposes an approach to assess the fiscal stance based on the nonresource primary balance that is simpler

\footnotetext{
${ }^{2}$ Gavin and Perotti (1997) and Talvi and Vegh (2000) are the classic earlier studies.
} 
and more reliable than other approaches used in the literature. Comparisons with the fiscal policies of middle-income NRECs in other regions are also presented to complement the analysis.

How did fiscal vulnerabilities to resource price shocks evolve during the recent cycle (Section IV)? Resource price shocks are a fact of life for LAC NRECs. In the past, because of financing and sustainability problems, sharp declines in these prices often led to the need to implement contractionary fiscal policies during downturns, with sudden and painful adjustments. Have the fiscal positions of LAC NRECs become more resilient to potential resource price shocks? Are there relationships between the fiscal policies implemented during the boom and current fiscal vulnerabilities to resource price shocks?

The paper assesses the fiscal vulnerability of NRECs in the region to changes in resource prices to derive the sensitivity of net financing requirements to these prices. In turn, this depends primarily on the size of the financial buffers that countries accumulated during the boom years.

Have the fiscal positions of LAC NRECs become more sustainable (Section V)? How did long-term fiscal sustainability in LAC NRECs evolve during the recent cycle? Are those developments linked to the degree of procyclicality during the boom?

The paper examines the long-term fiscal sustainability of NRECs in LAC and its evolution over the recent economic and resource price cycle. The approach used in the paper extends conventional debt sustainability analysis to take into account explicitly the exhaustibility of the resources in the ground. It also requires making explicit assumptions regarding intertemporal welfare.

- Finally, what was the role played by fiscal rules and resource funds in the various dimensions of fiscal policy during the recent cycle (Section VI)? Most NRECs in the region have put in place numerical fiscal rules and/or resource funds to help address the significant challenges that volatile, uncertain, and exhaustible resource revenues pose to fiscal management. In many cases, rules and funds have also been motivated by political economy considerations: they have been seen as potentially useful instruments to contain spending pressures or to enhance the government's credibility to manage resource revenues.

The paper looks at the role played by these mechanisms during the recent cycle. Fiscal rules and funds show wide variety of design among NRECs in the region: what were their main characteristics, and what was their implementation experience during the boom and the slump $?^{3}$ Were there links between the presence of rules or funds and the actual fiscal policy responses to the cycle? The paper highlights the complex design, implementation, and political economy issues for fiscal rules and funds in NRECs that are related to the volatility, uncertainty, and exhaustibility of resource revenues. It offers some suggestions for the design

\footnotetext{
${ }^{3}$ Appendix I provides a detailed description of the workings of the fiscal rules and funds implemented in the sample countries.
} 
of these mechanisms in NRECs based on conceptual considerations and lessons from country experiences.

\section{BACKGROUND}

The prices of nonrenewable resources recorded sharp swings in the last decade. This was particularly the case for oil, gas, copper, and zinc, critical resources for some Latin American countries. The peak annual average prices in real terms in 2006-08 were more than three times their 2001 values (Figure 1). ${ }^{4}$ The prices of those nonrenewable resources receded strongly afterwards, but are still on average twice as large as at the beginning of the decade. The pattern in those prices during the last decade can be discussed analytically as a price "cycle", with a "boom" period until 2008 and a downturn in 2009.

\section{Figure 1. Selected Nonrenewable Resource Prices in Real Terms} (Index, 2001=100)

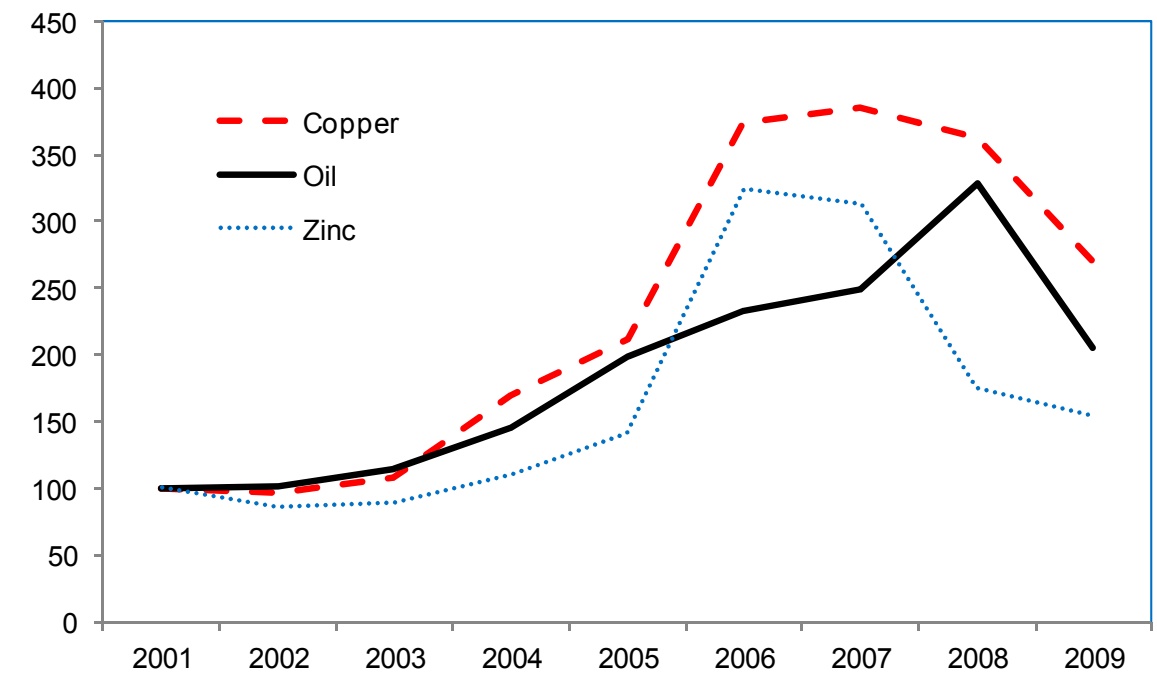

Source: IMF World Economic Outlook database.

The large increase in oil prices in real terms recorded during 2003-08, which was mainly demand-driven, took place together with a very strong expansion in global economic activity (Figure 2). This was in sharp contrast with the sizable weakenings in world GDP growth caused by the two adverse supply-driven spikes in oil prices recorded in the 1970s and early 1980s.

Nonrenewable resources are a critical source of fiscal revenue for some Latin American and Caribbean (LAC) countries (Table 1). This paper focuses on a sample of LAC nonrenewable resource-exporting countries (NRECs) where fiscal revenue from nonrenewable resources (based on readily available information) accounted for at least 20 percent of total fiscal

\footnotetext{
${ }^{4}$ The price of oil used in this paper is the IMF World Economic Outlook (WEO) basket of oil prices, which is a simple average of the prices for Brent, Dubai, and West Texas Intermediate grades.
} 
revenue over 2005-09: Bolivia, Chile, Ecuador, Mexico, Peru, Trinidad and Tobago, and Venezuela. ${ }^{5}$ These countries can be split into two groups: oil-exporting countries (OECs: Bolivia, Ecuador, Mexico, Trinidad and Tobago, and Venezuela) ${ }^{6}$ and mineral-exporting countries (MECs: Chile and Peru). Dependence on nonrenewable resource revenues is greater in LAC OECs (40 percent in 2005-09) than in LAC MECs (20 percent). This is partly due to a larger government take from oil than from minerals, as can be seen from comparing the ratios to GDP of fiscal resource revenue and resource sector size. ${ }^{7}$

\section{Figure 2. Oil Price Changes in Real Terms and Global Economic Growth}

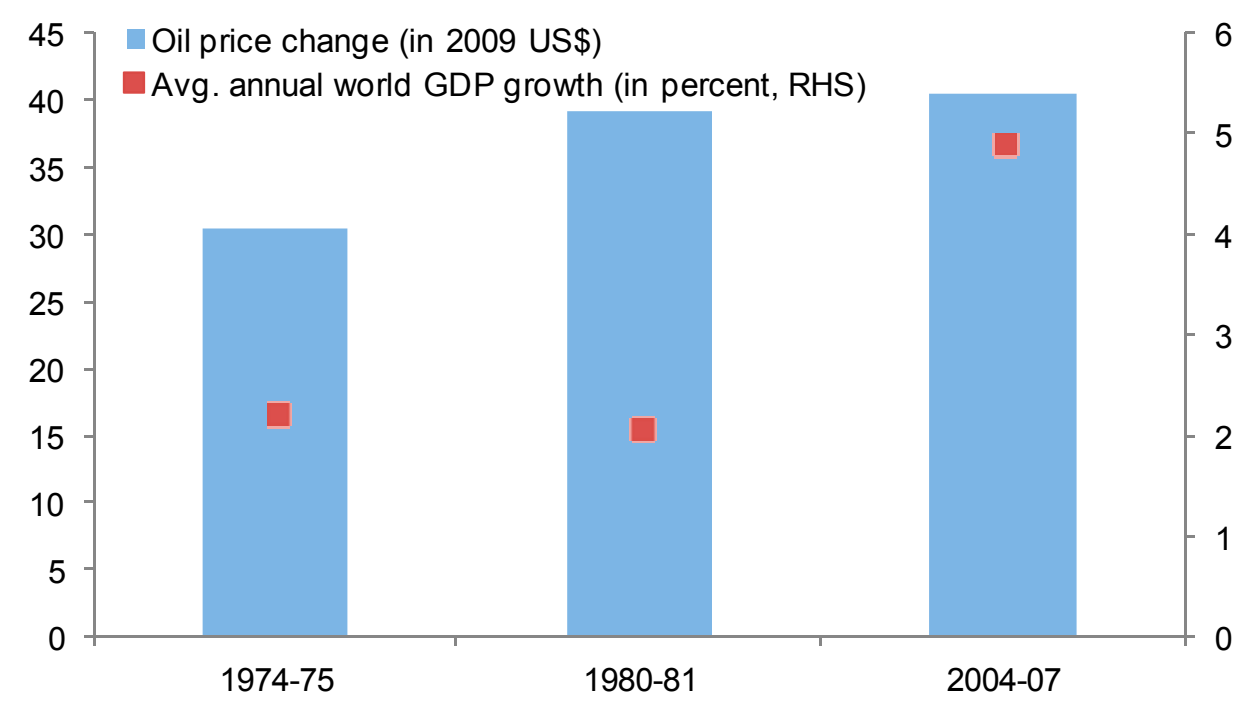

Source: IMF World Economic Outlook database.

\footnotetext{
${ }^{5}$ The coverage of the fiscal accounts refers to the nonfinancial public sector (NFPS) (i.e., including national resource companies) for Bolivia, Ecuador, Mexico, and Venezuela; the general government for Chile; and the central government for Peru (national definition that includes regional governments, which are the beneficiaries of the canon minero) and Trinidad and Tobago. Part of the operating expenditure of Venezuela's national oil company (PDVSA) has been imputed as nonresource spending to capture the company's extensive quasi-fiscal spending.

${ }^{6}$ Throughout this paper, the term "oil" is used as a substitute for the more encompassing terms "hydrocarbon" or "petroleum"; gas is the more important resource in Bolivia and Trinidad and Tobago.

${ }^{7}$ Some OECs record oil revenue net of implicit or explicit domestic fuel subsidies. Resource revenue dependency ratios would be higher if "gross" oil revenue figures were used (together with higher nonoil spending in the form of fuel subsidies).
} 
Table 1. Resource Sector Size and Revenue (Simple Averages, 2005-09)

\begin{tabular}{lrcc}
\hline & & \multicolumn{2}{c}{ Fiscal Resource Revenues } \\
\cline { 3 - 4 } & $\begin{array}{c}\text { Resource } \\
\text { Size } 1 /\end{array}$ & $\begin{array}{c}\text { In Percent of } \\
\text { Total } \\
\text { Revenues }\end{array}$ & $\begin{array}{c}\text { In Percent of } \\
\text { GDP }\end{array}$ \\
\hline Bolivia & 12 & 28 & 10 \\
Chile & 19 & 23 & 6 \\
Ecuador & 16 & 25 & 7 \\
Mexico & 8 & 36 & 8 \\
Peru & 11 & 20 & 3 \\
Trinidad and Tobago & 44 & 57 & 18 \\
Venezuela & 27 & 53 & 19 \\
OECs & 21 & 40 & 12 \\
MECs & 15 & 22 & 5 \\
\hline
\end{tabular}

Sources: IMF data and national sources.

1/ Resource sector in percent of GDP.

The specific characteristics of fiscal resource revenues bring about difficult challenges for fiscal policy design and implementation in NRECs:

- The high volatility and uncertainty of nonrenewable resource revenues complicate fiscal management, budgetary planning, and the efficient use of public resources. During the recent cycle in resource prices (2003-09), the volatility of total fiscal revenue in real terms in LAC NRECs was much higher than in a comparator group of LAC countries (Figure 3$) ;{ }^{8}$ the standard deviation of percentage changes of total revenue in real terms was 16 percent in the former compared to $4 \frac{1}{2}$ percent in the latter. $^{9}$

- The exhaustibility of the resources raises complex issues of intergenerational equity, in terms of how much to consume and save, as well as of long-term fiscal sustainability.

- With resource revenue largely arising from abroad, the fiscal spending of these resources domestically may generate inflationary pressures and lead to reduced competitiveness of nonresource export and import-competing sectors (Dutch Disease).

\footnotetext{
${ }^{8}$ Argentina, Brazil, Colombia, Costa Rica, Dominican Republic, Guatemala, Nicaragua, Panama, Paraguay, and Uruguay.

${ }^{9}$ In some countries, the increases in resource revenues during the recent boom were also due to changes in fiscal regimes aimed at increasing government take (e.g., Chile and Venezuela) and nationalizations (e.g., Bolivia, Ecuador, and Venezuela).
} 
In addition to the underlying characteristics of resource revenues, political economy and institutional factors (such as, for example, earmarking and revenue-sharing provisions in Ecuador and Bolivia, respectively) can add to the challenges noted above. They can exacerbate spending pressures, particularly when revenue is rising as in the 2003-08 boom.

Figure 3. Growth Rates of Fiscal Revenue in Real Terms

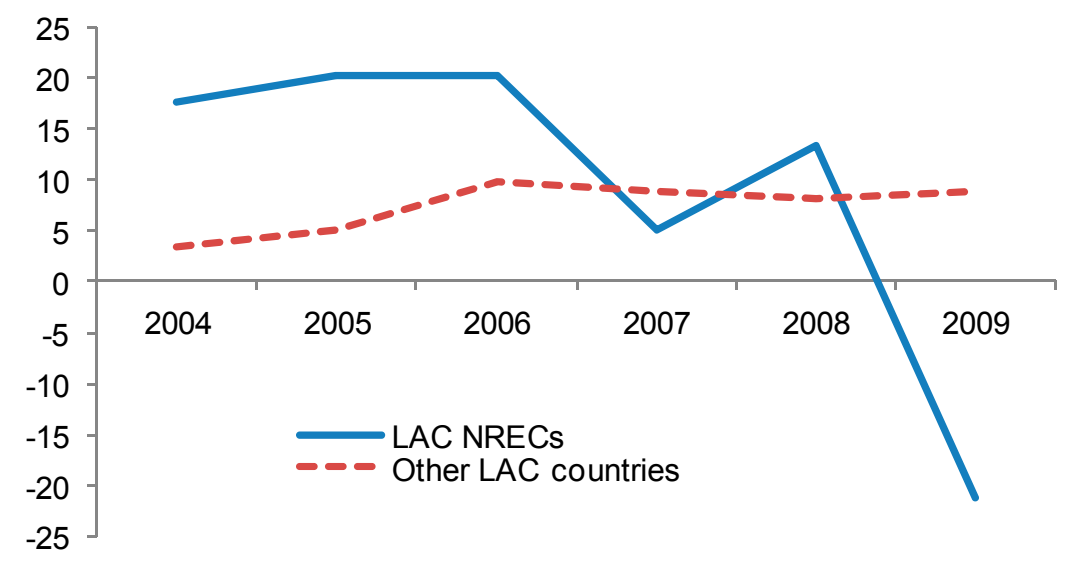

Sources: IMF data and national sources.

\section{Has Fiscal Policy Been Procyclical During the Recent Cycle?}

Has fiscal policy been expansionary in good times and contractionary in bad times? To what extent has fiscal policy helped to dampen business cycle fluctuations in NRECs? Our analysis starts by examining the evolution of one of the most widely used fiscal policy indicators, the primary balance-to-GDP ratio together with real GDP growth dynamics. We then discuss some important limitations of this approach and the ways in which the literature has attempted to address some of its shortcomings. Finally, we propose an alternative approach to assess the fiscal stance in the short run that is simpler and more reliable than other approaches used in the literature.

As background, the average growth rates of real GDP in LAC NRECs accelerated during 2003-08 but fell dramatically in 2009. All countries except Mexico experienced markedly higher growth rates during 2003-08 than in the previous six years..$^{10}$ In all countries there was a pronounced slowdown in 2009 and some countries recorded significant output declines.

Looking simply at the evolution of the primary balance-to-GDP ratio would suggest that in the majority of LAC NRECs fiscal policy was contractionary during 2003-08 and was uniformly expansionary in 2009 (Figure 4). The primary balance ratios improved in most countries during the boom and deteriorated in all countries in 2009.

\footnotetext{
${ }^{10}$ Mexico was an exception because of the strong recovery that followed the Tequila crisis in the mid 1990s.
} 
Figure 4. Changes in Primary Balances

(In percent of GDP)

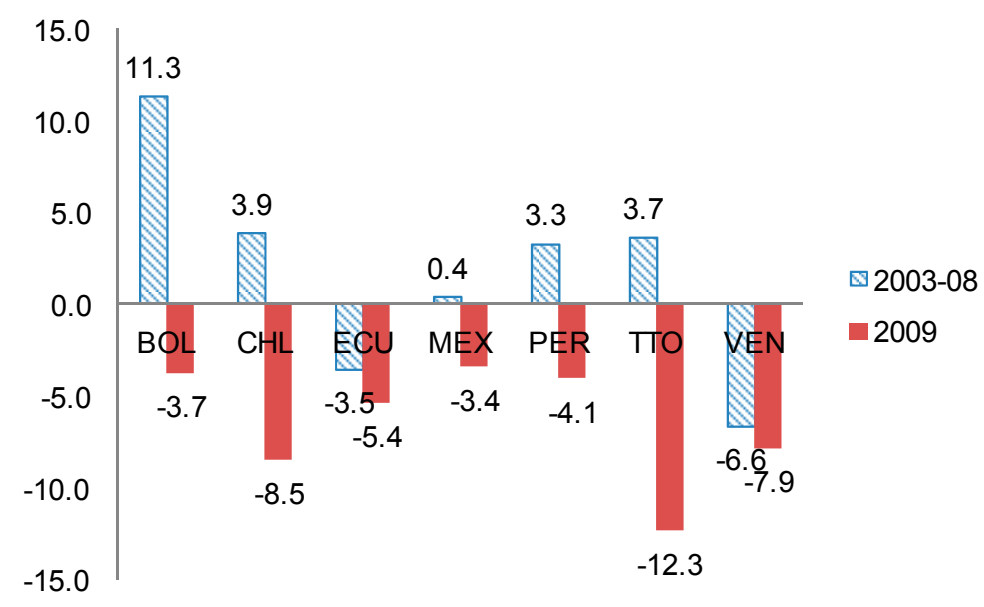

Sources: IMF data and national sources.

The combination of a seemingly contractionary fiscal policy with relatively high growth rates and a seemingly expansionary fiscal policy with low growth rates might suggest predominantly countercyclical fiscal policy responses to the economic cycle.

However, this type of assessment of the fiscal stance in NRECs based on primary balance ratios to GDP would be misleading for several reasons.

- In NRECs the primary balance is not a good indicator to assess the impact of fiscal policy on domestic demand because it does not take into account the specific nature of resource revenues. These largely originate from abroad and therefore do not affect the purchasing power of domestic economic agents. Thus, changes in the primary balance arising from fluctuations in these revenues should be expected to have limited effects on domestic demand.

- The analysis does not control for the influence of the nonresource economic cycle on nonresource government revenues.

- Resource prices can have major effects on the observed ratios of fiscal variables to GDP because the resource and nonresource GDP deflators can and often do deviate markedly, making nominal GDP quite volatile. Changes in resource prices can therefore drive large changes in conventional fiscal policy indicators that make their interpretation difficult. ${ }^{11}$

Alberola and Montero (2006), Izquierdo and Talvi (2008), and Vladkova-Hollar and

\footnotetext{
${ }^{11}$ For instance, a lower nonresource deficit in nominal terms might come hand in hand with a higher nonresource deficit-to-GDP ratio if, as a result of a decline in international resource prices, nominal GDP falls proportionally more than the nonresource deficit. Barnett and Ossowski (2003) provide examples.
} 
Zettelmeyer (2008) attempted to address the first and second issues mentioned above by distinguishing between resource and nonresource revenues, and by estimating separately the "structural" level for each. They defined structural fiscal balances as the sum of structural resource and nonresource revenues net of government expenditures, and characterized the fiscal stance by analyzing the changes in the estimated structural fiscal balances. ${ }^{12}$

A key drawback of this approach is that the "structural" level of resource revenues is subject to major estimation uncertainty resulting from the highly volatile and unpredictable evolution of resource prices and the nature of the stochastic process that drives them. ${ }^{13}$ In fact, Izquierdo and Talvi (2008) and Vladkova-Hollar and Zettelmeyer (2008) arrived at opposite conclusions on the fiscal stance during 2003-07 mainly because of differences in their assumptions about the persistence of resource price changes.

For the reasons discussed above, to assess the fiscal stance in NRECs, it is preferable to abstract from government resource revenue, eschew structural resource revenue estimates, and refrain from using total GDP as the scaling factor. The nonresource primary balance (NRPB) measured in percent of nonresource GDP (NRGDP) fulfils these requirements (Barnett and Ossowski, 2003; Medas and Zakharova, 2009). ${ }^{14}$

The evolution of the NRPB as a ratio to NRGDP tells a completely different story from that obtained from the primary balance (Figure 5). It suggests that fiscal policy in most LAC NRECs was expansionary during 2003-08, and was more mixed in 2009. This finding is, however, subject to the important caveat that the measured NRPB does not include domestic fuel subsidies (which are implicit in several countries) due to the difficulty of obtaining reliable, time-consistent, and methodologically uniform estimates for a number of countries (Appendix II). Appendix III sets out the main factors underlying the evolution of NRPBs in the sample countries.

To study the relationship between the fiscal stance and the economic cycle with more precision we need to measure the economic cycle more carefully and assess the NRPB adjusted for the influence of the cycle. We measure the nonresource economic cycle by quantifying the nonresource output gap (NROG) applying the standard Hodrick-Prescott filter to the annual time series of NRGDP in real terms. ${ }^{15}{ }^{16}$ The NROG is defined as actual

\footnotetext{
${ }^{12}$ Previous studies such as Gavin and Perotti (1997) and Talvi and Vegh (2000) did not attempt to estimate structural fiscal balances.

${ }^{13}$ In a major recent study of crude oil prices, Hamilton (2008) finds that the statistical evidence is consistent with the view that the price of oil in real terms seems to follow a random walk without drift. He notes that to predict the price of oil one quarter, one year, or one decade ahead it would not be at all naïve to offer as forecast the current price - though he emphasizes the enormous uncertainty surrounding such forecasts.

${ }^{14}$ This approach is therefore closer to Di Bella (2009), who also relied on the change in the NRPB to assess the fiscal stance in the short run but scaled it in percent of total GDP instead of NRGDP. As discussed above, this can lead to spurious estimated effects as changes in the ratio could be mainly driven by changes in the denominator resulting from changes in resource prices.

${ }^{15}$ We use the standard smoothing parameter for annual time series $\lambda=100$.
} 
NRGDP minus trend NRGDP (measured in percent of trend NRGDP). To address the endpoint problem of the HP filter we used NRGDP annual time series projections up to 2015 based on the IMF's latest WEO.

\section{Figure 5. Changes in Nonresource Primary Balances (In percent of Nonresource GDP)}

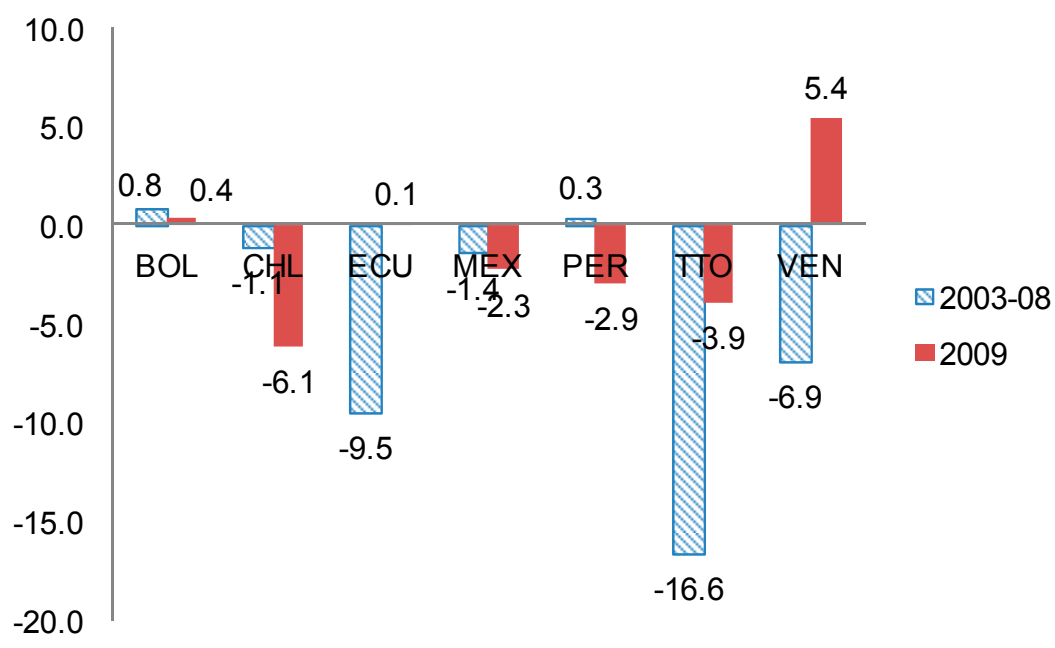

Sources: IMF data and national sources.

In this context, we define fiscal policy as either expansionary or contractionary. The starting point is that the NRPB can be broken down as the sum of the cyclically-adjusted NRPB and the cyclical NRPB. Then, fiscal policy is defined as contractionary when the change in the cyclically-adjusted NRPB (CANRPB) is positive ( $\triangle$ CANRPB $>0$ ), and is expansionary when the change is negative $(\triangle \mathrm{CANRPB}<0)$.

Following the standard methodology to compute cyclically-adjusted balances (Fedelino, Ivanova, and Horton, 2009), we estimate the CANRPB for each country during 2003-09 using the following formula:

$$
\text { canrpb }=r\left(1-\varepsilon^{\mathrm{r}}\right) \mathrm{NROG}-\mathrm{g}\left(1-\left(\varepsilon^{\mathrm{g}}-1\right)\right) \text { NROG }
$$

where canrpb is the cyclically-adjusted NRPB measured in percent of NRGDP, $r$ is the ratio of nonresource revenues to NRGDP, $\varepsilon^{\mathrm{r}}$ is the elasticity of nonresource revenues with respect

\footnotetext{
${ }^{16}$ An alternative method would be to use the production function approach (Giorno and others, 1995). However, estimates of the cycle based on this method require the availability of reliable data on the use of labor and capital stocks for the nonresource sector. As regards the decomposition of a series into a trend and a cyclical component, the methodologies include: the Beveridge-Nelson approach, the unobservable component approach, the Baxter-King filter, and the Hodrick-Prescott filter. Each of them entails some advantages and drawbacks. We chose the Hodrick-Prescott filter because it is simple, transparent, and continues to be the most commonly used filter in empirical studies and policy analysis.
} 
to the NROG, $\mathrm{g}$ is the ratio between expenditures and NRGDP, and $\varepsilon^{\mathrm{g}}$ is the elasticity of expenditures with respect to the NROG. ${ }^{17} \mathrm{We}$ call "fiscal impulse" an expansionary fiscal policy (i.e., $\Delta$ canrpb $<0$ ).

To assess whether fiscal policy is countercyclical or procyclical, we have to examine the link between changes in the NROG and the change in canrpb. If the change in the NROG is negative (positive), then expansionary (contractionary) fiscal policy entails a countercyclical fiscal stance. Expansionary (contractionary) fiscal policy in the face of a positive (negative) change in the NROG implies a procyclical fiscal policy. ${ }^{18}$

Using this methodology it is found that fiscal policy in LAC NRECs was predominantly procyclical during 2003-08. ${ }^{19}$ Figure 6 shows the change in the NROG and the fiscal impulses for each country during the period. ${ }^{20}$ The change in the NROG was positive in all countries and was particularly high in Venezuela. The fiscal impulses were positive in all countries except Bolivia. They were very substantial in Ecuador, Trinidad and Tobago, and Venezuela. The combination of positive changes in NROGs with positive fiscal impulses implies a procyclical fiscal policy response. The degree of procyclicality (measured by the ratio of fiscal impulse to changes in the NROG) was relatively more pronounced in the case of Ecuador and Trinidad and Tobago (Table 2). The degree of procyclicality can also be measured in Figure 6 as the slope of the ray from the origin to the point corresponding to each country. It can be seen that the slope of the rays is highest for Trinidad and Tobago and Ecuador.

The degree of procyclicality of fiscal policy in our sample of LAC NRECs during the boom was lower on average than in a comparator sample of 13 middle-income NRECs outside the

\footnotetext{
${ }^{17}$ We assume that $\varepsilon^{\mathrm{r}}=1$ and $\varepsilon^{\mathrm{g}}=0$ for all countries. The approach assumes that no major tax policy changes took place. Most studies in developing countries assume that $\varepsilon^{\mathrm{g}}=0$ mainly because of the absence of extended unemployment insurance schemes. We assume that $\varepsilon^{r}=1$ following Vladkova-Hollar and Zettelmeyer (2008) who estimate nonresource income elasticities controlling for changes in tax structure and find that they are close to unity in most cases.

${ }^{18}$ We follow Fedelino, Ivanova, and Horton (2009) in linking the change in canrpb (i.e., the fiscal impulse) to changes in the NROG to assess the cyclicality of the fiscal response. In contrast, Alberola and Montero (2006) study the link between fiscal impulses and the level of the output gap. We find the former approach more appealing, in part because the estimation of the direction of changes in output gaps is arguably more reliable than the estimation of the specific level of the output gap.

${ }^{19}$ In this paper, we follow the literature on the cyclical behavior of fiscal policy, which implicitly assumes that output shocks drive fiscal policy. However, some authors (e.g., Rigobon, 2004) claim that fiscal policy shocks drive output and not the other way around, suggesting that the conventional wisdom of procyclical fiscal policy in developing countries might not be well founded. These reverse causality considerations might be particularly relevant in some NRECs where nonresource economic activity is dominated by government spending.

However, Ilzetzki and Vegh (2008) rely on a battery of econometric tests to show that causality goes in both directions. In addition, they show that the evidence of procyclical fiscal policy in developing countries is robust to endogeneity considerations.

${ }^{20}$ We computed the cumulative change in the NROG and the cumulative fiscal impulse during 2003-08.
} 
region. ${ }^{21}$ The median fiscal impulse normalized by the change in the NROG was 0.5 in LAC NRECs compared with 1.1 in the comparator group. This would seem to be explained in part by the fact that the average size of the resource sector and of resource revenues relative to GDP in the comparator group is substantially higher than in LAC NRECs. ${ }^{22}$ Thus, in the comparator countries, the same proportional fiscal use of additional resource revenues would result, other things being equal, in a higher fiscal impulse relative to NRGDP because of the smaller size of the latter relative to windfall resource revenues.

Figure 6. NRECs: Fiscal Impulses and Nonresource Output Gaps, 2003-08

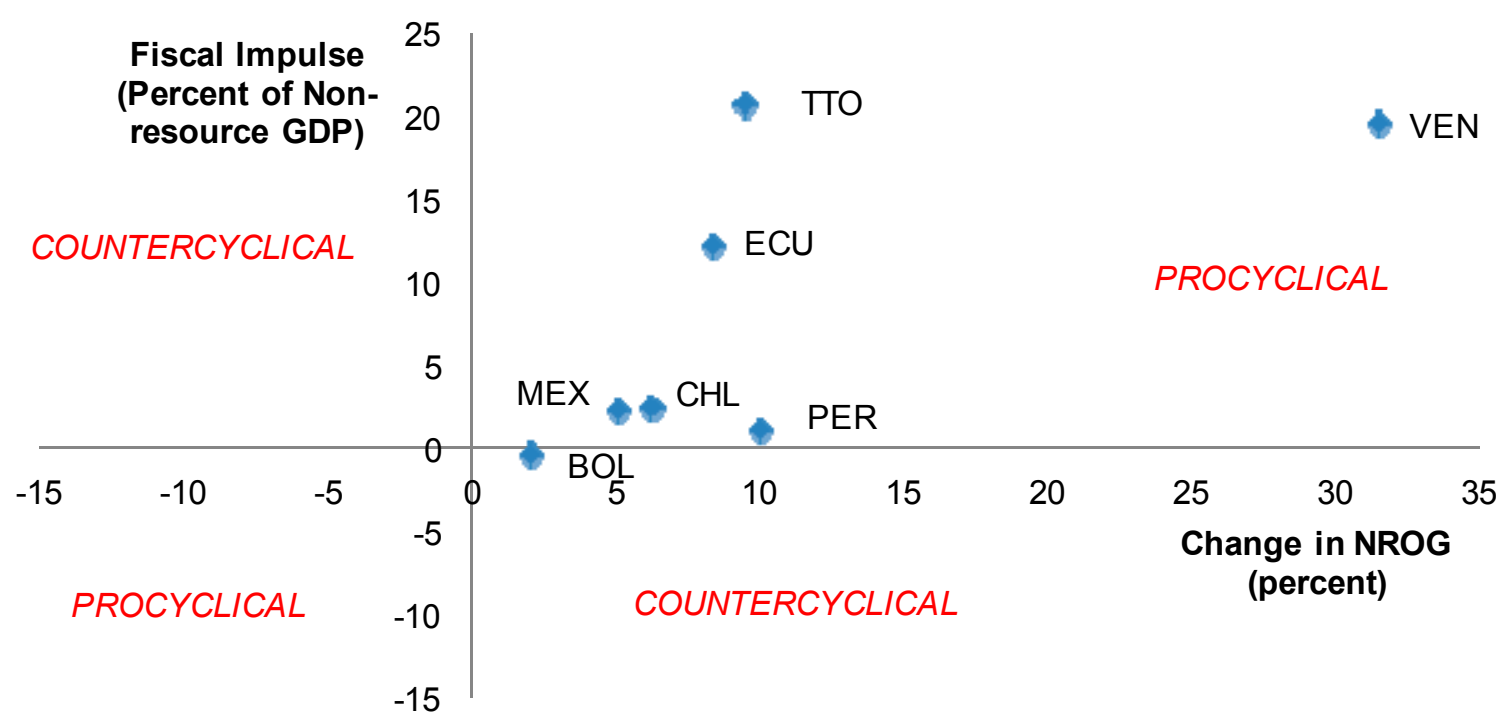

Sources: IMF data and national sources.

In the 2009 downturn, the change in the NROG was negative in all countries except Bolivia and was particularly large in Mexico and Trinidad and Tobago (Figure 7). The fiscal impulses were positive only in Chile and Peru, indicating the implementation of a countercyclical fiscal policy response in those countries. Fiscal policy was relatively neutral in Mexico and Trinidad and Tobago, procyclical in Ecuador, and highly procyclical in Venezuela.

In the downturn, and in marked contrast to the boom, the degree of procyclicality in LAC NRECs was higher than in the comparator group of NRECs. The median fiscal impulse normalized by the change in the output gap was 0.1 compared to -1.2 in the other countries. Thus, the average fiscal response in the comparator countries was more countercyclical in the downturn. Government net financial positions are an important factor that may help explain

\footnotetext{
${ }^{21}$ The sample of countries comprises Algeria, Angola, Azerbaijan, Cameroon, Congo, Gabon, Indonesia, Iran, Kazakhstan, Libya, Russia, Sudan, and Timor Leste.

${ }^{22}$ The average size of the resource sector in LAC NRECs is 16 percent of GDP compared to 43 percent in the comparator group. The average resource revenue-to-GDP ratio is 8 percent of GDP in LAC NRECs compared to 19 percent in the comparator group.
} 
the different fiscal responses. In LAC NRECs most governments were net financial debtors in 2008 while most governments in the comparator countries were net financial creditors. This suggests that LAC NRECs had relatively less room for maneuver to implement expansionary fiscal policies than the comparator countries.

Figure 7. NRECs: Fiscal Impulses and Nonresource Output Gaps, 2009

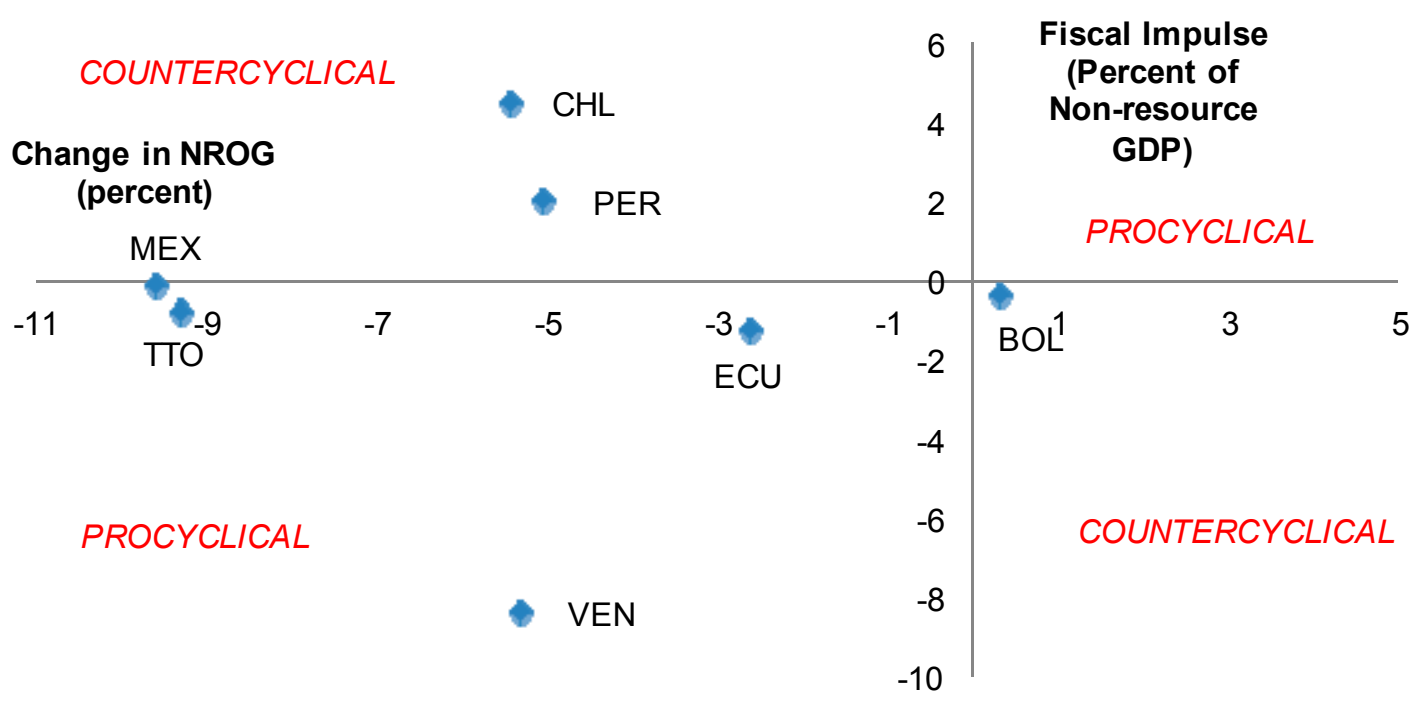

Sources: IMF data and national sources.

The evidence suggests that the procyclical fiscal policy bias was more prominent in the boom. ${ }^{23}$ Table 2 shows the degree of fiscal policy procyclicality during 2003-08 and in 2009 . The average degree of procyclicality (measured by the ratio between the fiscal impulse and the change in the NROG) was 0.75 during the boom and -0.04 during 2009.

The evidence also suggests that the countries that had more conservative fiscal policies during the boom tended to be those that implemented more expansionary fiscal policies during the slowdown in 2009. ${ }^{24}$ During the boom, fiscal policy was close to neutral in Peru and mildly procyclical in Chile; in both countries it was strongly countercyclical during the crisis. In Mexico, fiscal policy was mildly procyclical during the boom and relatively neutral during the crisis. Bolivia was a special case combining a mild countercyclical fiscal policy response during the boom and in 2009. In contrast, fiscal policy was procyclical in Ecuador, Trinidad and Tobago, and Venezuela during the upswing and the downswing (except in Trinidad and Tobago where it was neutral in 2009).

\footnotetext{
${ }^{23}$ This asymmetry of fiscal policy has been documented for a large sample of developing and advanced countries by Balassone and Kumar (2007). It could suggest that political economy factors that result in strong spending pressures in good times might have played a more important role than financing constraints in explaining the cyclical behavior of fiscal policy.

${ }^{24}$ Di Bella (2009) arrived to a similar conclusion in a larger sample of Latin American countries.
} 
Table 2. Fiscal Impulses and Nonresource Output Gaps

\begin{tabular}{lrrrrrrrr}
\hline & \multicolumn{3}{c}{$2003-2008$} & & \multicolumn{3}{c}{2009} \\
\cline { 2 - 5 } \cline { 6 - 8 } & FI & dNROG & Fl/dNROG & & FI & dNROG & Fl/dNROG \\
\hline Bolivia & -0.3 & 2.0 & -0.13 & & -0.3 & 0.3 & -1.12 \\
Chile & 2.6 & 6.2 & 0.43 & & 4.6 & -5.5 & -0.84 \\
Ecuador & 12.3 & 8.3 & 1.49 & & -1.1 & -2.7 & 0.43 \\
Mexico & 2.4 & 5.0 & 0.49 & & -0.1 & -9.6 & 0.01 \\
Peru & 1.2 & 9.9 & 0.13 & & 2.1 & -5.1 & -0.41 \\
Trinidad and Tobago & 20.9 & 9.3 & 2.24 & & -0.7 & -9.3 & 0.07 \\
Venezuela & 19.8 & 31.5 & 0.63 & & -8.4 & -5.3 & 1.56 \\
\hline
\end{tabular}

dNROG = change in NROG (in percent)

$\mathrm{FI}=$ Fiscal impulse (in percent of NRGDP)

Sources: IMF data and national sources.

As will be seen in later sections, there are links between the degree of procyclicality during the boom and the current degree and/or dynamics of fiscal vulnerability and long-term fiscal sustainability. Broadly speaking, the fiscal positions of the countries that had the most procyclical responses to the boom are also those that are currently most exposed to resource price shocks and/or those whose sustainability may be in question. In contrast, the countries that pursued the least procyclical policies during the upswing currently enjoy relatively comfortable fiscal vulnerability and sustainability positions. In addition, it will be seen that there seems to have been no obvious link between the cyclical stance of fiscal policy and the presence of fiscal rules and/or resource funds across countries during the cycle.

\section{Short-Term Fiscal Vulnerability to Resource Price Shocks}

Resource price shocks are a fact of life for NRECs. The prices in real terms of copper, oil, and zinc experienced annual average (absolute) changes of around 20-25 percent during 1970-2009. In turn, sharp declines in those prices have often led to sudden and painful fiscal adjustments and financing problems, as shown by many OECs in the mid-1980s and mid1990s. In addition, access to external credit markets has historically tended to be procyclical. ${ }^{25}$ Even though a number of current projections suggest an upward path in resource prices over the medium term, the recent swings in resource prices (e.g., oil prices collapsed from a peak of almost US $\$ 150$ per barrel in mid-2008 to US\$35 per barrel in early2009) provide a sobering reminder of potential price volatility. In addition, the still significant downside risks to the global recovery cannot be ignored. Against this background, it is important to examine the resilience of fiscal positions of LAC NRECs to potential resource price shocks. Have countries learnt from the past and reduced their fiscal vulnerability to those shocks?

\footnotetext{
${ }^{25}$ Gavin and Perotti (1997) and Kaminsky, Reinhart, and Vegh (2004).
} 
The analysis in the preceding section already provided some hints regarding the ability of the sample countries to respond to resource price shocks, as some countries had to undertake contractionary fiscal policies in 2009 . This section carries out a more systematic and forward-looking analysis by contrasting potential net/gross financing requirements resulting from resource price shocks against the financial asset stocks that governments accumulated in previous years. ${ }^{26}$ The results of this analysis are not clear a priori, as fiscal vulnerability could have increased during the last decade due to greater dependence on resource revenues in the region, larger nonresource deficits, and sizable overall fiscal deficits in the downturn. ${ }^{27}$ On the other hand, some countries accumulated sizable financial assets (and reduced debt) that could be tapped to smooth any needed adjustment to lower resource prices. Policy and institutional reforms may also have increased the resilience of countries to negative shocks.

A simple way to assess the fiscal impact of a resource price shock is to assume local linearity between resource prices and fiscal revenue and, by extension, the overall fiscal balance and the gross financing requirement (i.e., the fiscal deficit plus amortizations due). To illustrate, this paper computes the impact of a hypothetical 15 percent fall in prices relative to the IMFprojected 2010 levels (in line with the median absolute change in prices over the last 40 years or between the $3^{\text {rd }}$ and $2^{\text {nd }}$ quartile of the distribution of negative changes) and applies a proportional adjustment to the projected resource revenues and resource GDP for 2010, while keeping nonresource revenue and spending unchanged (i.e., the same nonresource balance in nominal terms). ${ }^{28}$

This approach helps isolate the specific impact of changes in resource prices, but has some drawbacks: it does not account for different effective rates of taxation across prices, and it abstracts from possible responses to lower resource prices (such as depreciation of the currency, increases in nonresource revenue, or reductions in government spending) or automatic declines in intergovernmental transfers arising from revenue-sharing provisions and in fuel subsidies. ${ }^{29}$ Despite these shortcomings, this simple approach is useful to assess the fiscal impact of a resource price shock and the capacity of governments to manage it.

\footnotetext{
${ }^{26}$ This exercise may have become more relevant in the wake of the recent global financial crisis and the tightening of financing conditions, as it assumes that the estimated fiscal deficits and gross financing requirements must be financed out of the government's financial assets and, by association, out of public sector external assets. This assumption, however, might be considered extreme for some countries with relatively developed domestic financial markets.

${ }^{27}$ Dependence on resource revenues in the sample countries increased on average from 20 percent of total fiscal revenue in 2003 to 26 percent in 2009.

${ }^{28}$ Projected 2010 fiscal figures were used in this exercise and in the next section to avoid making analytical assessments of fiscal vulnerability and long-term fiscal sustainability based on the unsettled conditions prevailing in 2009.

${ }^{29}$ Admittedly, an automatic reduction in shared resource revenue would just transfer the fiscal adjustment to other levels of government (e.g., Bolivia, Venezuela). However, the extent to which this is effective depends on the ability of the government to resist pressures for offsetting transfers and the ability of other beneficiary public entities to adjust to lower transfers.
} 
Based on this methodology, the overall fiscal balance would fall more significantly in OECs than in MECs (Table 3). The fiscal impact of a decline of 15 percent in mineral prices would be around $1 / 2$ percent of GDP in Chile and Peru, while a similar decline in oil prices would have a fiscal impact of $3 \frac{1}{2}$ percent of GDP in Venezuela. These results reflect the larger share of oil revenue in fiscal revenues and total GDP in OECs relative to mining revenue in MECs. More importantly, the average overall deficit in OECs would be close to the peak recorded in 2009 and gross financing requirements would average 11 percent of GDP in those countries. These values contrast greatly with those for Chile and Peru, where gross financing requirements would increase only to 3-4 percent of GDP.

Table 3. Fiscal Impact of a 15 Percent Fall in Resource Prices

\begin{tabular}{lcccc}
\hline & $\begin{array}{c}\text { Change in } \\
\text { Overall } \\
\text { Balance in } \\
\text { \% of GDP }\end{array}$ & $\begin{array}{c}\text { Implied } \\
\text { Overall } \\
\text { Balance in of GDP } \\
\text { \% }\end{array}$ & $\begin{array}{c}\text { Implied Gross } \\
\text { Financing } \\
\text { Requirement in of GDP }\end{array}$ & $\begin{array}{c}\text { Implied Overall } \\
\text { Deficit in \% of } \\
\text { Gov. Financial } \\
\text { Assets }\end{array}$ \\
\hline Bolivia & -1.6 & -1.9 & 7.0 & 10.2 \\
Chile & -0.7 & -2.4 & 4.2 & 15.1 \\
Ecuador & -1.2 & -5.2 & 7.1 & 54.7 \\
Mexico & -1.1 & -4.6 & 12.7 & 39.4 \\
Peru & -0.4 & -0.8 & 3.4 & 8.9 \\
Trinidad and Tobago & -2.4 & -6.6 & 12.9 & 36.7 \\
Venezuela & -3.6 & -7.7 & 14.0 & 50.8 \\
\hline
\end{tabular}

Source: Fund staff estimates on the basis of projected 2010 IMF WEO figures.

Table 3 also shows the ratio of the overall fiscal deficits after the shock (and gross financing requirements) to gross government/NFPS domestic financial assets (i.e., deposits with the banking system) and government foreign assets. ${ }^{30}{ }^{31}$ On this measure, Ecuador is highly exposed to resource price shocks, with net financing needs after the assumed shock representing 55 percent of available government financial assets, a fact exacerbated by its lack of access to international capital markets following its 2008 debt default. To a lesser extent, Mexico, Trinidad and Tobago, and Venezuela would also be exposed to a resource price shock. $^{32}$

\footnotetext{
${ }^{30}$ In some countries, government deposits are the main counterpart of international reserves on the balance sheet of central banks.

${ }^{31}$ In Chile and Trinidad and Tobago savings in their resource funds are separate from the stock of international reserves held by the central bank.

${ }^{32}$ An extension, particularly relevant for the countries with fixed exchange rates regimes, is to measure the implied coverage of public external assets (i.e., central banks' net international reserves plus resource funds) in terms of months of imports of goods and services. In Ecuador, this external vulnerability indicator would fall to below two months of imports.
} 
How has the short-term fiscal vulnerability to negative resource price shocks evolved during the last cycle? By undertaking a similar sensitivity analysis on the fiscal figures for 2003applying a 15 percent fall to resource prices prevailing that year-it is striking that fiscal exposure to resource price shocks has increased in Ecuador and Venezuela, as much larger fiscal deficits have not been offset by increases in government financial assets. Fiscal exposure to shocks fell substantially in Bolivia and Peru due to improvements in their overall fiscal balances and higher financial assets, and remains broadly unchanged in the other NRECs in LAC (Table 4).

The evidence shows links between procyclical fiscal policies during the boom and fiscal vulnerability. Broadly speaking, the fiscal positions of countries that implemented procyclical fiscal policies during the upswing tend to be those that are currently most exposed to resource price shocks and/or those whose exposure to shocks has increased.

Table 4. Evolution of Fiscal Vulnerability Indicators

\begin{tabular}{lrrrr}
\hline & $\begin{array}{c}\text { Implied Overall Deficit in } \\
\text { \% of Gov. Financial } \\
\text { Assets }\end{array}$ & $\begin{array}{c}\text { Implied NIR+Resource } \\
\text { Funds Coverage in Months } \\
\text { of Imports }\end{array}$ \\
\cline { 2 - 5 } & 2003 & 2010 & 2003 & 2010 \\
\hline Bolivia & 105.9 & 10.2 & 7.2 & 19.0 \\
Chile & 9.2 & 15.1 & 8.0 & 8.0 \\
Ecuador & -2.5 & 54.7 & 1.4 & 1.6 \\
Mexico & 45.9 & 39.4 & 3.3 & 3.8 \\
Peru & 27.8 & 8.9 & 3.8 & 12.8 \\
Trinidad and Tobago & -3.1 & 36.7 & 6.4 & 16.3 \\
Venezuela & 39.5 & 50.8 & 15.5 & 10.1 \\
\hline
\end{tabular}

Source: Fund staff estimates on the basis of actual 2003 and projected 2010 IMF WEO figures.

Finally, fiscal vulnerability exercises should be combined with assessments of the overall policy framework and its ability to help deal with negative shocks to resource prices and volumes. In this regard, reforms in the last two decades have made many of the countries in the sample more resilient to those shocks. ${ }^{33}$

- The introduction of inflation targeting frameworks in Chile, Peru, and Mexico has strengthened the central bank's mandate for maintaining low and stable inflation rates while increasing the flexibility of exchange rates to adapt to changes in external conditions.

- Fiscal institutions have been reformed, with varied success, including through strengthened revenue administration, improvements in public financial management,

\footnotetext{
${ }^{33}$ See IMF, Regional Economic Outlooks, various issues, and Fernandez-Arias and Montiel (2009) for a more thorough discussion.
} 
reductions in budget rigidities, greater fiscal transparency, and the introduction of fiscal responsibility legislation, fiscal rules, and resource funds (Section VI and Appendix I provide an analysis of fiscal rules and resource funds for the countries in the sample).

- The composition of public debt has changed dramatically in LAC NRECs, with the largest share now being denominated in local currency and with a longer average maturity. This said, Ecuador's policy framework, for example, is less flexible to tackle potential financing shortfalls (in contrast to Mexico) due to the absence of monetary and exchange rate policies under its fully dollarized regime.

\section{LONG-TERM FISCAL SUSTAINABILITY}

Some observers have argued that the sustainability of fiscal policies in the region has improved in the recent past. How did long-term fiscal sustainability in LAC NRECs evolve during the recent cycle? Are those developments linked to the degree of procyclicality of fiscal policy during the boom?

Analyses of fiscal sustainability often focus on a comparison between the observed cyclically-adjusted primary balance against a debt-stabilizing primary balance. This approach is combined with a "reasonable" objective for the debt to GDP ratio. ${ }^{34}$ In NRECs, however, the analysis needs to take into account explicitly two critical issues: (i) the exhaustibility of resource revenues; and (ii) the existence of sizable financial asset stocks accumulated by some of those countries during the boom. The first issue is particularly relevant for the countries with a limited production horizon for existing resource reserves, like Mexico and Trinidad and Tobago. ${ }^{35}$ On the other hand, a focus on gross debt is misleading for countries such as Trinidad and Tobago and Chile, which were able to turn part of their hydrocarbon/mineral wealth into financial assets during the boom.

With these key considerations in mind, this paper assesses long-term fiscal sustainability by comparing the cyclically-adjusted NRPB (i.e., removing the impact of cyclical factors from the assessment of the actual fiscal policy stance) against a long-term or benchmark NRPB.

The computation of the latter requires two steps:

- First, the calculation of government net wealth, defined in this paper as the sum of the present value of projected future resource revenues (evaluated at the prices prevailing in the respective year of analysis - e.g., 2010 prices for the 2010 sustainability benchmark) plus net government financial assets. Estimating the present value of future resource revenue requires assumptions about future resource prices; resource reserves in the ground; production profiles; production costs; the government take;

\footnotetext{
${ }^{34}$ See for example Fernández-Arias and Montiel (2009) for a recent application to Latin American countries. Reinhart, Rogoff, and Savastano (2003) provide a discussion of debt "tolerance" in Latin America.

35 The ratio of proven reserves to production at the end of 2009 was less than 15 years for Mexico and Trinidad and Tobago, less than 40 years for Chile, Ecuador and Peru, and more than 50 years for Bolivia and Venezuela.
} 
real interest rates and returns on financial assets; and the path of the real exchange rate (i.e., the domestic purchasing power of resource revenue).

- Second, the derivation of a consumption (or spending) path out of government net wealth (i.e., the NRPB). This requires making intertemporal welfare choices regarding how much resource revenue to consume now versus how much to save for consumption by future generations. For this purpose, the literature has typically relied on alternative variants of the permanent income hypothesis (PIH) and consumption smoothing over time. ${ }^{36}$ The application of the PIH approach has usually involved the calculation of perpetuities, either constant in real terms or growing in line with population growth or the rate of growth of GDP. ${ }^{37}$

These two steps are subject to uncertainty and face difficult issues regarding intertemporal welfare choices:

- The estimation of the wealth from future resource revenue is complicated by uncertainty about many of the parameters mentioned above. This is especially the case for future resource prices, but there are other sources of uncertainty for the countries in the sample. For instance, Peru has a large mining potential (yet to be properly measured) but, on the other hand, some of its proven reserves might not be exploited at all because of social concerns (e.g., Río Blanco). ${ }^{38}$

- The intertemporal welfare choice regarding consumption and savings paths can be controversial, particularly in light of ever-expanding social needs. The implications of using a PIH-based approach or any other alternative are not trivial and lead to different consumption/savings paths, and therefore different intergenerational distribution of the resource wealth.

Despite these caveats, fiscal sustainability exercises can be useful benchmarks for fiscal policy analysis and formulation in a longer term perspective when properly designed and with due consideration for the specific circumstances of each country. Furthermore, the benchmarks should be reassessed from time to time as new information becomes available.

This paper computes a long-term fiscal benchmark based on a PIH formulation, but with an important difference relative to the traditional perpetuity-based approaches described above. These approaches are relatively stringent, as they require the stock of government wealth to

\footnotetext{
${ }^{36}$ Similar judgments about intertemporal welfare choices are made in the debt sustainability analysis (DSA) for other countries but are usually not made explicit. For example, the stabilization of the public debt in percent of GDP has major implications for the intertemporal allocation of taxes and public spending. See Barnett and Ossowski (2003) for a formal derivation, Maliszewski (2009) and van der Ploeg (2008) for comparative assessments, and Carcillo, Leigh, and Villafuerte (2007) for a specific application.

${ }^{37}$ See for example, Carcillo, Leigh, and Villafuerte (2007), Baunsgaard (2003), and Clausen (2008).

${ }^{38}$ Reserves, production profiles, and government takes can also change substantially over time with price changes, as documented by the literature on the so-called "expropriation cycles" (see for example Hogan and Sturzenegger, 2010).
} 
increase over time through savings, including out of the return on financial investments. They would also not be realistic on policy grounds for countries with short resource production horizons and limited net financial assets, as spreading the consumption of oilrelated wealth too far into the future would require large savings by current (probably poorer) generations. Instead, in this paper an annuity (at constant prices) is estimated on the basis of the total government wealth over the remaining production period (the reserves to production ratio in number of years) plus 15 years. ${ }^{39}$ This is an ad hoc formulation, but is less stringent than other approaches and more realistic for some countries in the sample. The long-term annuity out of total government wealth is compared to the cyclically-adjusted NRPB as the relevant measure of its current consumption. Appendix IV offers details about the methodology and assumptions used, as well as an illustrative simulation for a representative NREC.

The comparative sustainability analysis over time and across countries in the sample can be facilitated by presenting the results in terms of the ratio of the implied long-term primary nonresource expenditure relative to the actual primary nonresource expenditure (this implicitly assumes an unchanged nonresource revenue ratio to NRGDP in the future). A "fiscal sustainability ratio" lower than 1 means that the country would have to adjust to reach the sustainable benchmark (for instance, if the ratio is 0.8 , by an equivalent of 20 percent of the current level of expenditures), while a value greater than 1 would imply a sustainable fiscal position. The main results of this analysis are as follows (Figure 8):

- The IMF WEO-projected 2010 fiscal stance (the cyclically-adjusted NRPB), were it to be maintained unchanged into the future, would not be sustainable in the long run for Ecuador and Trinidad and Tobago; and sustainability questions would also emerge for Mexico and Venezuela. Potential "adjustments" would range from 25 percent of primary nonoil expenditure in Trinidad and Tobago to 10 percent in Mexico. ${ }^{40}$ By contrast, the fiscal position in Bolivia, Chile, and Peru would be more or less in line with the sustainability benchmark. ${ }^{41}{ }^{42}$

- When comparing the sustainability position in 2010 relative to 2003 (before the boom in resource prices), Ecuador, Trinidad and Tobago, and Venezuela recorded substantial deteriorations, mainly because of a large expansion in their nonresource primary deficits relative to the increases in government net wealth. (Countries above the 45 degree line in Figure 8 improved their fiscal sustainability position between

\footnotetext{
${ }^{39}$ This sustainability analysis has a "static" dimension in that it focuses on the fiscal position in one specific year at a time based on the information then available. A "sustainability gap" can be closed in subsequent years in various ways, including through higher nonresource revenue, reductions in spending, or changes in the fiscal regime of the resource sector. These factors can only be captured explicitly in a dynamic setting.

${ }^{40}$ As indicated earlier, domestic fuel subsidies, despite being sizable in several countries, were not included in the NRPB due to the difficulty of obtaining reliable estimates over time in several countries and different fiscal accounting treatment across countries.

${ }^{41}$ Under the perpetuity approach all countries were running unsustainable fiscal policies in 2010.

${ }^{42}$ This analysis assumes that domestic fuel subsidies are eliminated at some point in the future. Otherwise, the fiscal adjustment needed would be larger, and in some cases substantially so. For instance, in Ecuador these subsidies are estimated to have amounted to more than 8 percent of NRGDP in 2008.
} 
2003 and 2010, whereas countries below the line recorded a deterioration). These results are somewhat surprising given that between 2003 and 2010 the oil price more than doubled in real terms and proven reserves increased substantially in Ecuador and Venezuela. However, these factors were more than offset by the increased nonoil deficits, the reduced domestic purchasing power of higher oil revenue due to appreciations of the currency in real terms (particularly in Venezuela), and the reduced size of the oil wealth relative to a growing nonoil sector. By contrast, the long-term sustainability positions barely changed in Chile, Mexico, and Peru, and improved in Bolivia.

- The countries whose fiscal responses to the boom were most procyclical are also those that currently show the weakest long-term fiscal sustainability positions and/or those where fiscal sustainability deteriorated during the cycle.

Figure 8. Fiscal Sustainability Ratios 2003 and 2010

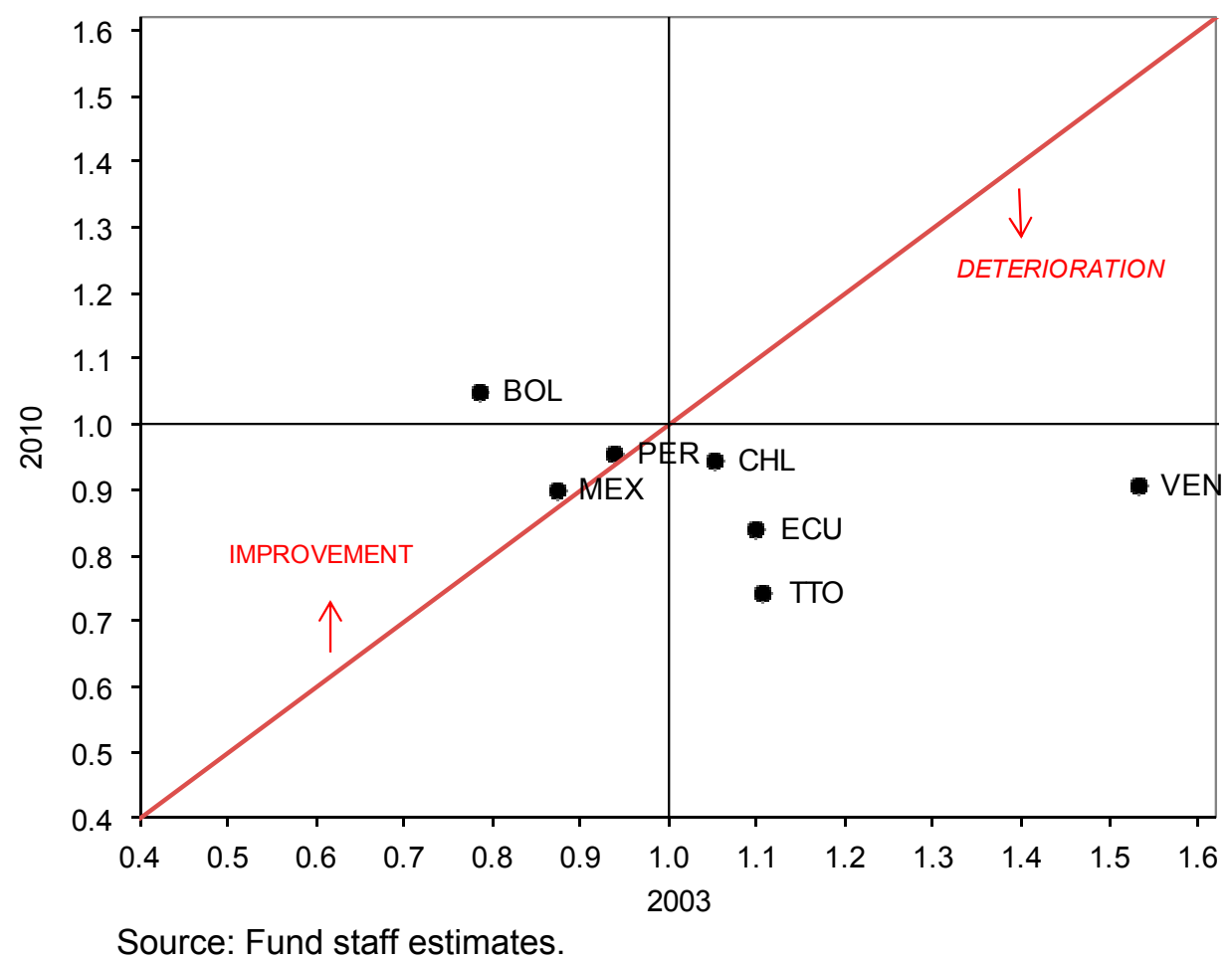

Finally, it is worth stressing that long-term unsustainable positions do not necessarily imply the need for immediate adjustment, although the issue may be more pressing for countries with short remaining production horizons. Fiscal sustainability assessments have to be updated from time to time, given that the estimation of long-term sustainability benchmarks is subject to considerable uncertainty. In addition, governments could reap sufficient fiscal dividends (through higher nonresource revenue) from higher government spending to keep their 2010 levels (in percent of NRGDP, for example). However, the latter will depend on the quality of government spending, its impact on economywide productivity levels, and the government's ability to reap fiscal dividends from the additional activity - as well as on the quality of overall policies, institutions, and decision making. 


\section{Fiscal Rules ANd Resource Funds DURING The CyCle}

Most NRECs in the region have introduced numerical fiscal rules or fiscal guidelines and/or nonrenewable resource funds (NRFs) in the expectation that these institutional features may help address the challenges that uncertain, volatile, and exhaustible resource revenues pose to fiscal management. ${ }^{43}$ In many cases, fiscal rules and funds have also been motivated by political economy considerations: they have been seen as potentially useful instruments to contain spending pressures or to enhance the government's credibility.

This section looks at the role played by these mechanisms during the recent cycle. There has been a wide variety of fiscal rules and funds among NRECs in the region: what are their main characteristics, and what was their implementation experience during the boom and the slump? Were there links between the presence of rules or funds and the fiscal responses to the cycle? The section also offers some suggestions for the design of these mechanisms in NRECs based on conceptual considerations and lessons from country experiences.

Six of the seven countries covered in this study have, or have had at some point during the last decade, one or both of these mechanisms: fiscal rules and NRFs (Chile, Ecuador, Mexico, and Venezuela); fiscal rules (Peru); and NRFs (Trinidad and Tobago). Bolivia is the only country in the group not to have put in place such mechanisms. The design and implementation experience of rules and funds in the NRECs in the region are discussed in detail in Appendix I.

The design of fiscal rules and NRFs has varied widely among the sample countries:

- Chile: fiscal rule (2001) targeting the structural central government balance (which comes close to targeting the cyclically-adjusted nonresource balance given the adjustment made for the price of copper), which underwent successive technical refinements over time and was relaxed twice; and a price-contingent copper stabilization fund that was later replaced by two NRFs: a fund with flexible rules where overall fiscal surpluses are deposited and from which resources can be drawn if desired, and a fund with a pre-specified range for annual deposits as a ratio to GDP. ${ }^{44}$

- Ecuador: originally three fiscal rules (2002) targeting the nonresource balance, the rate of growth of expenditure in real terms, and the public debt, which were modified (some expenditures were excluded from the coverage of the spending rule) and

\footnotetext{
${ }^{43}$ Fiscal rules are defined here as standing commitments to specified numerical targets for some key budget aggregates. Unlike fiscal rules, fiscal guidelines are not legally binding. This is the case in Chile. In what follows, however, for simplicity reference will be made to Chile's "fiscal rule".

${ }^{44}$ Most nonrenewable resource stabilization funds around the world have rigid price- or revenue-contingent deposit and withdrawal rules, whereby deposits and withdrawals depend on the realization of an outcome (resource price or revenue) relative to a specified trigger. In contrast, most savings funds have rigid noncontingent deposit rules which typically require the annual deposit of a fixed share of revenues into the fund. Finally, some financing funds have flexible operational mechanisms more closely aligned with overall balances.
} 
subsequently replaced by a nonoil golden rule (2008); and a series of NRFs which had various operational rules - including trigger rules contingent on actual oil prices relative to budgeted prices, and rigid deposit rules. The last of these NRFs was abolished a few years ago.

- Mexico: fiscal rule (2006) targeting the overall budget balance; and NRFs with trigger rules contingent on actual oil prices relative to budgeted prices. Both underwent modifications: some expenditures were excluded from the coverage of the rule, and subsequently the rule was temporarily relaxed; the caps on the accumulated resources in some of the funds were suspended.

- Peru: fiscal rules (1999) targeting the overall balance and the rate of growth of expenditure in real terms, which were modified several times: the fiscal balance targets and expenditure growth ceilings were relaxed, and some expenditures were removed from the coverage of the spending rule.

- Trinidad and Tobago: NRFs with trigger rules contingent on actual oil revenues relative to budgeted revenues.

- Venezuela: multi-year fiscal rules (2000) targeting the current balance, the rate of growth of expenditure in real terms, and the public debt (which have not been implemented); and a NRF with oil price trigger rules which were frequently modified as circumstances and policy objectives changed.

On the whole, and mirroring developments with fiscal rules and funds in NRECs elsewhere in the world, the experience of LAC NRECs with these mechanisms has been mixed.$^{45}$ There seems to have been no obvious link between the presence of fiscal rules and NRFs and the cyclicality of fiscal policy across LAC NRECs during the recent cycle:

- In Chile (fiscal rule and NRFs) and Peru (fiscal rules) fiscal policies were - at mostmoderately procyclical during the boom, and countercyclical during the slump.

- Bolivia conducted fiscal policies broadly similar to those of the countries above without these mechanisms.

- In Mexico (fiscal rule and NRFs), the degree of procyclicality of fiscal policy increased following the establishment of the rule and the funds in the latter part of the boom, and policy was neutral in the downswing.

- Ecuador (fiscal rules and NRFs), Venezuela (fiscal rules and NRFs) and Trinidad and Tobago (NRFs) conducted the most procyclical fiscal policies during the boom, and their policies were also procyclical or neutral during the slump.

In other words, fiscal rules and NRFs were associated with a broad range of fiscal responses to the recent economic and resource price cycles, including highly procyclical responses. In

\footnotetext{
${ }^{45}$ For a general review of international experience with fiscal rules and NRFs in NRECs and econometric analysis of their effectiveness, see Ossowski and others (2008). Bacon and Tordo (2006) provide a detailed operational review of many oil funds. Arezki and Ismail (2010) evaluated econometrically some aspects of the effectiveness of fiscal rules in OECs, and Shabsigh and Ilahi (2007) of oil funds.
} 
part, this is the result of the many modifications that rules and funds underwent in many countries as circumstances and policy objectives changed (see below and Appendix I). ${ }^{46}$ This said, in some countries these mechanisms may have had some disciplining and credibilityenhancing effects. For instance, in Peru the expenditure rule, while undergoing several modifications, seems to have helped anchor the fiscal policy formulation process and moderate procyclicality. These effects are difficult to test empirically, however, particularly when the rules and funds have been in place for just a few years in a context where the external environment and many other factors were also changing - dramatically in some cases.

Many factors could potentially explain the variety of outcomes with rules and funds. They range from design issues to institutional and political economy aspects, such as political support and commitment to the rule or fund, consensus, fiscal transparency, sound public financial management, and adequate monitoring and control. Although a detailed examination of these issues is beyond the scope of this paper, the next subsections highlight some critical lessons arising from the working of fiscal rules and funds in LAC NRECs.

\section{Fiscal rules}

In consonance with the experience of NRECs in other regions, it has been difficult to design and implement fiscal rules in LAC NRECs that can withstand the volatility and uncertainty of nonrenewable resource revenues and the rapidly changing economic environments facing these countries - particularly in countries that are more heavily dependent on resource revenues, namely the OECs in the sample.

During the boom and in a situation of abundant liquidity generated by resource revenues, a number of rules targeting the nonresource balance and the rate of growth of expenditure were tested by mounting expenditure pressures. These pressures may have been based in part on growing perceptions as time went by that the resource price increases were "permanent." As a result, the rules were changed over time, sometimes several times (Ecuador, Peru), were not complied with (Ecuador), or were not implemented (Venezuela). The Chilean structural balance rule, while undergoing technical modifications over time, was met throughout the period in a situation of strong consensus and political support for the rule, but was eased in the last year of the boom. Rules targeting the overall balance, on the other hand, were more easily met, particularly as the increase in resource prices accelerated during the latter years of the boom (Peru). But they also implied or allowed procyclical fiscal policies (Mexico). In Peru the expenditure rule seems to have provided a more binding constraint during the upswing.

\footnotetext{
${ }^{46}$ An analysis of the link between the presence of fiscal rules and/or NRFs in OECs around the world and the degree of fiscal policy procyclicality during the recent oil price cycle based on Villafuerte and López-Murphy (2010) does not show statistically significant differences in the fiscal policy responses of countries with such mechanisms and countries without them.
} 
As resource prices fell precipitously and recession set in in a number of LAC NRECs, rules targeting the overall balance came under pressure and were modified or suspended invoking exceptional clauses (Mexico and Peru; in Peru the spending rule was also eased to undertake a countercyclical fiscal response). In Chile, the structural balance rule was relaxed further, and methodological changes of various types introduced, to accommodate an easing of fiscal policy.

The frequent changes to fiscal rules and compliance difficulties in most LAC NRECs during the recent economic cycle highlight the complex design, implementation, and political economy issues associated with the volatility and unpredictability of nonrenewable resource revenues, and the difficult tradeoffs between rigidity, flexibility, and credibility in the design of rules. Rigid rules can be easily overcome by events, undermining their credibility. Excessive flexibility can increase uncertainty about the direction of fiscal policy.

The experience of LAC NRECs with fiscal rules suggests a number of lessons for successful strategies that are consistent with those emanating from NRECs in other regions (TerMinassian, 2010).

- Targeting the overall balance in NRECs is procyclical and can result in major swings in expenditure (which is made hostage to the vagaries of resource prices). Targeting nonresource balances (adjusted for the nonresource cycle if technically and institutionally feasible) or alternative structural balances as in Chile (supplemented by some feedback loop from the debt or the overall deficit if the initial fiscal or financial position is precarious) can help smooth spending, decouple it from resource revenues in the short run, and reduce procyclicality. The appropriate level of the targeted nonresource balance has to take into account long-term fiscal sustainability and fiscal vulnerability to resource shocks.

- Some flexibility in the design of fiscal rules, as well as escape clauses, are advisable in NRECs that face large uncertainties about relevant macroeconomic factors (including resource prices) and are heavily exposed to unpredictable exogenous shocks. As regards flexibility, the targets could be specified for a period of a few years and periodic revisions based on medium- and long-term reassessments undertaken; or revision clauses could be introduced specifying the conditions under which the targets may be revised; or rolling targets could be used - though this may weaken discipline and carry credibility costs if used inappropriately. In all cases, transparent, clear and specific escape clauses for unpredictable and major shocks should be put in place.

- Other key technical elements and preconditions for a successful strategy include added emphasis on a medium-term perspective, a minimum set of public financial management requirements, and fiscal transparency.

- Consensus and political commitment to the rules are vital for their success. Rules that are not buttressed by broad social and political agreement over their objectives are unlikely to be effectively implemented and in cases of major political volatility can easily end up being ignored. 


\section{Nonrenewable resource funds}

Almost all the funds put in place by NRECs in the region have (or have had) rigid (contingent or non-contingent) accumulation and withdrawal rules - the recent Social and Economic Stabilization Fund in Chile being the notable exception. The implementation of funds with rigid rules was premised largely on the expectation that the removal of "high" resource revenues relative to some benchmark or of a fixed share of revenues from the budget would help moderate and stabilize public spending, reduce the room for discretion in fiscal policy, and foster savings.

In practice setting fixed trigger resource prices or revenues in contingent NRFs has proved difficult, owing to the characteristics of the stochastic process generating these prices. Given the large resource price volatility, uncertainty, and shock persistence, it is very challenging to set estimated long-term average prices that are supposed to remain unchanged over time. As a result, funds with such trigger rules either had their rules modified frequently and their operations temporarily suspended (Venezuela), or after undergoing modifications of the trigger rules were replaced by funds with different rules (Chile, copper stabilization fund), or were eliminated (Ecuador). Some funds where deposits and withdrawals are contingent on realized resource prices or revenues relative to the prices or revenues set in the budget have proved more resilient (Mexico, Trinidad and Tobago) but in certain circumstances can complicate asset and liability management and, if the budgeted resource revenue or price is not set by formula, can provide incentives for the strategic setting of resource prices or revenues in the budget. The fund in Ecuador where deposits were based on a fixed share of certain oil revenues was abolished after a few years of operation.

The experience with NRFs in countries in the region also shows that tensions can easily surface between rigid-rule NRFs and overall fiscal policy and asset management. For example, in Venezuela, given the overall stance of fiscal policy, at times the required deposits into the NRF could only be made by issuing debt at high interest rates; this led to temporary suspensions of the operations of the fund. In Ecuador, the combination of rigid deposit rules into the NRF, extensive revenue earmarking, and cash fragmentation led to the implementation of schemes to bypass the restrictions placed by the NRF, including the domestic placement of debt subsequently "bought-back" by the NRF.

In most NRECs in the region that have or have had NRFs with rigid operational rules, these operate in conjunction with fiscal rules (Trinidad and Tobago being the exception). When overall fiscal policy is constrained by fiscal rules, the rationale for funds with separate rigid operational rules is unclear. And this set up may lead to conflicting objectives, thereby complicating asset and liability management, as shown for instance by Ecuador. Rather, if there is a desire for a NRF, the existence of a fiscal rule would argue for establishing a financing fund with flexible accumulation and withdrawal rules and clear asset management objectives, which would ensure its effective integration with the budget.

As noted above, it has been argued that NRFs with rigid operational rules contribute to the moderation of spending because they remove certain resources from the budget during upswings. It is useful to disentangle the technical and political economy aspects of the issue. 
- At a purely technical level, this would be the case if there are strong liquidity constraints and the NRF rules are binding and they are observed. However, if the government is running large surpluses, it is not clear why removing some resources from the budget would moderate spending. And in the absence of surpluses, since resources are fungible, the government can borrow or run down other financial assets to increase spending and make the required deposits in the NRF - or it can ignore the NRF rules.

- This still leaves possible political economy arguments for rigid NRF rules: even if there are no liquidity constraints, rules that mandate deposits into a fund can influence the political process in the direction of moderating spending. The evidence suggests, however, that the political economy advantages of removing resources from the budget are often unclear, that when pressures are mounting the funds' rules can be changed, bypassed, or ignored, and that the results seem to be very country-specific.

- On the other hand, rigid NRF rules can have significant fiscal costs in terms of suboptimal asset and liability management, as illustrated by the examples cited above.

The evidence of a number of LAC NRECs therefore suggests that the focus should be on overall fiscal policy; that NRFs with rigid operational rules would best be avoided; and that if there is a preference for having a NRF, consideration should be given to financing funds with flexible rules that are well integrated with budget systems and fiscal policy frameworks.

Some countries have made efforts in the last few years to better integrate their NRFs with budget systems and fiscal policy frameworks. Chile replaced its rigid-rule contingent fund with a flexible-rule stabilization and savings fund where overall fiscal surpluses are deposited and from which deficits can be financed. The usefulness of such a fund was shown in 2009 when the deficit was largely financed by drawings from the fund. Mexico suspended temporarily the statutory caps on the resources held in some of its NRFs, which had been a source of procyclicality and inefficiency (as resources accumulated in excess of the caps were earmarked for extrabudgetary expenditures, and these expenditures did not compete for resources with spending included in the budget).

\section{Conclusions}

This paper examined several dimensions of fiscal policy in NRECs in LAC during the last decade, including the fiscal stance of these countries from a short-run stabilization perspective; their short-term fiscal vulnerability to sudden falls in resource prices; and the long-term sustainability of their fiscal policy stance. The paper then looked at the role played by fiscal rules and resource funds and their relative performance with regard to these various dimensions of fiscal policy.

Fiscal policy was found to be predominantly procyclical in LAC NRECs during the boom, as most countries, particularly Ecuador and Trinidad and Tobago, relaxed their fiscal policies during the upswing. In the 2009 downturn, the differences in the fiscal policy stance were more marked across these countries, with a countercyclical policy in Bolivia, Chile, and Peru, a neutral one in Mexico and Trinidad and Tobago, and procyclical in Ecuador and Venezuela. The evidence also suggests that procyclicality was, on average, more prominent 
during the boom years. The non-uniform responses to the slump can be partly linked to the fiscal policy stance during the boom: countries displaying more conservative fiscal policies in 2003-08 implemented more expansionary fiscal policies, on average, during the 2009 crisis.

The paper found links between the degree of procyclicality during the boom and the current degree and/or dynamics of fiscal vulnerability and long-term fiscal sustainability. Broadly speaking, the countries that had the most procyclical responses to the boom are also those whose fiscal positions are currently most vulnerable to resource price shocks and/or those whose sustainability may be in question. In contrast, the countries that pursued the least procyclical fiscal policies during the upswing currently enjoy relatively comfortable fiscal vulnerability and sustainability positions.

In terms of short-term fiscal vulnerability to resource price shocks, the analysis suggests that Ecuador, and to a lesser extent Mexico, Trinidad and Tobago, and Venezuela, would be affected more strongly by such shocks. When examining the evolution of fiscal vulnerability positions during the recent cycle, Bolivia and Peru reduced them substantially, while the fiscal exposure to resource price shocks of Ecuador and Venezuela increased. The analysis also indicates that the current fiscal positions of Ecuador, Mexico, Trinidad and Tobago, and Venezuela, if maintained into the future, would pose challenges to long-term sustainability.

The empirical analysis in this paper would allow to classify LAC NRECs into groups according to the fiscal policies implemented during the last decade. Fiscal policies in Bolivia, Chile, and Peru played a more stabilizing role during the cycle while becoming more sustainable in the short- and long-terms. In contrast, fiscal policies in Ecuador, Trinidad and Tobago, and Venezuela were mostly procyclical (and sometimes highly so), contributing to a deterioration in their (short- and long-term) sustainability positions. Mexico ran mildly procyclical policies during the boom and faces long-term sustainability challenges, but was able to keep its fiscal vulnerability and long-term sustainability positions broadly unchanged over time.

Most NRECs in the region have put in place fiscal rules and/or NRFs in response to the difficult challenges brought about by fiscal dependence on volatile, uncertain, and exhaustible resources. The experience of LAC NRECs with fiscal rules and NRFs has been mixed, mirroring developments in NRECs elsewhere in the world. The evidence suggests no obvious link between the presence of fiscal rules and NRFs and the cyclicality of fiscal policy across LAC NRECs during the recent cycle. Indeed, rules and NRFs were associated with a broad range of fiscal responses, including highly procyclical responses. In part, this reflects frequent modifications introduced to them in a number of countries as circumstances and policy objectives changed. In some other countries, by contrast, fiscal rules and NRFs seem to have had some disciplining and credibility-enhancing effects.

The design and implementation of fiscal rules and NRFs in NRECs is very challenging owing to the volatility and uncertainty of nonrenewable resource revenues, the rapidly changing economic conditions, and the need for supportive political and institutional environments. The lessons extracted from the region suggest some key elements for 
successful strategies. As regards fiscal rules: targeting nonresource balances (adjusted for the nonresource cycle, or alternative structural balances as in Chile, if feasible); clear mechanisms for the modification of targets based on medium- and long-term reassessments if appropriate; an enhanced medium-term perspective for fiscal policy; transparent, clear and specific escape clauses; a minimum set of public financial management requirements; fiscal transparency; and strong political support for the rules. As regards NRFs: rigid operational rules would preferably be avoided; and funds should be well integrated with budget systems and fiscal policy frameworks. 


\section{References}

Alberola, Enrique, and José Manuel Montero, 2006, "Debt Sustainability and Procyclical Fiscal Policies in Latin America,” Bank of Spain Working Paper 0611 (Madrid: Bank of Spain).

Arezki, Rabah, and Kareem Ismail, 2010, "Boom-Bust Cycle, Asymmetrical Fiscal Response and the Dutch Disease," IMF Working Paper 10/94 (Washington: International Monetary Fund).

Bacon, Robert, and Silvana Tordo, 2006, Experiences with Oil Funds: Institutional and Financial Aspects (Washington: World Bank).

Balassone, Fabrizio, and Manmohan Kumar, 2007, "Cyclicality of Fiscal Policy," in Promoting Fiscal Discipline, ed. by Manmohan Kumar and Teresa Ter-Minassian (Washington: International Monetary Fund).

Barnett, Steven, and Rolando Ossowski, 2003, "Operational Aspects of Fiscal Policy in Oil Producing Countries," in Fiscal Policy Formulation and Implementation in OilProducing Countries, ed. by Jeffrey M. Davis, Rolando Ossowski, and Annalisa Fedelino (Washington: International Monetary Fund).

Baunsgaard, Thomas, 2003, "Fiscal Policy in Nigeria: Any Role for Rules?" IMF Working Paper 03/155 (Washington: International Monetary Fund).

BP, Statistical Review of World Energy, June 2009.

Carcillo, Stéphane, Daniel Leigh, and Mauricio Villafuerte, 2007, "Catch-Up Growth, Habits, Oil Depletion, and Fiscal Policy: Lessons from the Republic of Congo," IMF Working Paper 07/80 (Washington: International Monetary Fund).

Clausen, Jens, 2008, "Calculating Sustainable Non-Mineral Balances as Benchmarks for Fiscal Policy: The Case of Botswana," IMF Working Paper 08/117 (Washington: International Monetary Fund).

Clemente, Lino, Robert Faris, and Alejandro Puente, 2002, "Dependencia de los Recursos Naturales, Volatilidad, y Desempeño Económico en Venezuela: El Papel de un Fondo de Estabilización," Proyecto Andino de Competitividad (Caracas: Corporación Andina de Fomento).

Daude, Christian, Angel Melguizo, and Alejandro Neut, 2010, "Fiscal Policy in Latin America: Countercyclical and Sustainable at Last?," OECD Development Centre Working Paper No. 291 (Paris: Organisation for Economic Co-operation and Development) 
Di Bella, Gabriel, 2009, "Fiscal Policy Response to the Crisis: How Much Room for Countercyclical Fiscal Policy?" in Regional Economic Outlook: Western Hemisphere October 2009 (Washington: International Monetary Fund).

Fedelino, Annalisa, Anna Ivanova, and Mark Horton, 2009, "Computing Cyclically Adjusted Balances and Automatic Stabilizers," Technical Notes and Manuals, Fiscal Affairs Department (Washington: International Monetary Fund).

Fernández-Arias, Eduardo, and Peter Montiel, 2009, “Crisis Response in Latin America: Is the Rainy Day at Hand?" IDB Research Department Working Paper 686 (Washington: Inter-American Development Bank).

Gavin, Michael, and Roberto Perotti, 1997, "Fiscal Policy in Latin America," in NBER Macroeconomics Annual 1997, ed. by Julio Rotemberg and Ben Bernanke (Cambridge, Massachusetts: MIT Press).

Giorno, Claude, Pete Richardson, Deborah Roseveare, and Paul van den Nord, 1995, "Estimating Potential Output, Output Gaps and Structural Budget Balances," OECD Economics Department Working Paper No. 152 (Paris: Organisation for Economic Co-operation and Development).

Hamilton, James, 2008, “Understanding Crude Oil Prices,” Working Paper (San Diego: Department of Economics, University of California).

Hogan, William, and Federico Sturzenegger, 2010, The Natural Resources Trap, (Cambridge, Massachusetts: MIT Press).

Ilzetzki, Ethan, and Carlos Vegh, 2008, "Procyclical Fiscal Policies in Developing Countries: Truth or Fiction?" NBER Working Paper 14191 (Cambridge, Massachusetts: National Bureau of Economic Reasearch).

International Monetary Fund, 2003, "Chile: Report on Observance of Standards and CodesFiscal Transparency" (Washington DC).

International Monetary Fund, 2010, IMF Fiscal Monitor May 2010, Navigating the Fiscal Challenges Ahead (Washington DC).

Izquierdo, Alejandro, and Ernesto Talvi, 2008, “All That Glitters May Not Be Gold: Assessing Latin America's Recent Macroeconomic Performance" (Washington: Inter-American Development Bank).

Kaminsky, Graciela, Carmen Reinhart, and Carlos Vegh, 2004, "When It Rains, It Pours: Procyclical Capital Flows and Macroeconomic Policies," NBER Working Paper 10780 (Cambridge, Massachusetts: National Bureau of Economic Reasearch). 
Maliszewski, Wojciech, 2009, "Fiscal Policy Rules for Oil-Producing Countries: A WelfareBased Assessment," IMF Working Paper 09/126 (Washington: International Monetary Fund).

Medas, Paulo and Daria Zakharova, 2009, “A Primer on Fiscal Analysis in Oil-Producing Countries,” IMF Working Paper 09/58 (Washington: International Monetary Fund).

Ossowski, Rolando, Mauricio Villafuerte, Paulo Medas, and Theo Thomas, 2008, Managing the Oil Revenue Boom: The Role of Fiscal Institutions, IMF Occasional Paper No. 260 (Washington: International Monetary Fund).

Reinhart, Carmen, Kenneth Rogoff, and Miguel Savastano, 2003, "Debt Intolerance”, NBER Working Paper 10015 (Cambridge, Massachusetts: National Bureau of Economic Research).

Rial, Isabel, 2010, "Performance of Alternative Fiscal Rules: An Application to Peru," Country Report 10/99 (Washington: International Monetary Fund)

Rigobon, Roberto, 2004, “Comments on When It Rains It Pours: Pro-cyclical Capital Flows and Macroeconomic Policies," in NBER Macroeconomics Annual, edited by Mark Gertler and Kenneth Rogoff (Cambridge, Massachusetts: MIT Press).

Shabsigh, Ghiath and Nadeem Ilahi, 2007, "Looking Beyond the Fiscal: Do Oil Funds Bring Macroeconomic Stability?” IMF Working Paper 07/96 (Washington: International Monetary Fund).

Talvi, Ernesto and Carlos Vegh, 2000, "Tax Base Variability and Procyclical Fiscal Policy," NBER Working Paper 7499 (Cambridge, Massachusetts: National Bureau of Economic Research).

Ter-Minassian, Teresa, 2010, "Preconditions for a Successful Introduction of Structural Fiscal Balance-Based Rules in Latin America and the Caribbean: a Framework Paper," unpublished manuscript.

van der Ploeg, F. and A. Venables, 2008, "Harnessing Windfall Revenues in Developing Economies: Sovereign Wealth Funds and Optimal Tradeoffs Between Citizen Dividends, Public Infrastructure and Debt Reduction,” CEPR Discussion Paper 6954.

Villafuerte, Mauricio and Pablo López-Murphy, 2010, "Fiscal Policy in Oil Producing Countries During the Recent Oil Price Cycle," Working Paper 10/28 (Washington: International Monetary Fund).

Vladkova-Hollar, Ivanna and Jeromin Zettelmeyer, 2008, "Fiscal Positions in Latin America: Have They Really Improved?” IMF Working Paper 08/137 (Washington: International Monetary Fund). 


\section{APPENDIX I}

\section{Fiscal Rules and Resource Funds in LAC Nonrenewable Resource Exporting Countries}

\section{Chile (structural balance rule and resource funds)}

Since 2001, Chile's fiscal policy has been built on the concept of a central government structural balance. This framework has been intended to signal fiscal policy intentions, while limiting procyclical policies and allowing full operation of automatic stabilizers from the revenue side. Under the structural balance rule, government expenditures are ex-ante budgeted in line with estimated structural revenues, i.e., revenues that would be achieved if the economy were operating at full potential and the prices of copper and molybdenum were at their long-term levels. ${ }^{47}$ The expenditure envelope is in turn split into an "inertial" component (i.e., legal and contractual obligations, multi-year commitments, and operating expenses) and a fraction for the creation of new spending programs or the expansion of existing ones. However, the authorities have also aimed at meeting the structural balance targets ex-post by undertaking any needed (intra-yearly revenue and expenditure) adjustments during budgetary execution.

Compliance with structural balance targets in Chile is not legally binding. However, successive governments reiterated their commitment with set targets and mostly complied with them. The 2006 Fiscal Responsibility Law (FRL) institutionalized key aspects of the structural balance rule framework (without forcing the government to commit to a specific target nor specifying procedures for its calculation) and complemented the fiscal framework with the introduction of two funds (the Social and Economic Stabilization Fund and the Pension Reserve Fund).

In clear contrast to other countries in the region, most fiscal powers in Chile are vested in the President and the executive branch (IMF, 2003). This means that the structural balance rule mainly acts as a constraint self-imposed and self-assessed by the executive. In this context, changes to this fiscal framework have been introduced through policy papers issued by the Budget Office (DIPRES), including the migration of accounting standards to the 2001 IMF Government Financial Statistics Manual, an expansion in its institutional coverage (to the consolidated central government, i.e., including extrabudgetary transactions from the Ley Reservada del Cobre), and changes in the numerical targets.

The structural balance target has changed over time. It was originally set at a surplus of 1 percent of GDP based on three grounds: (i) the structural operating deficit and negative net worth of the Central Bank of Chile; (ii) the existence of contingent liabilities related primarily to state-guaranteed minimum pensions and old-age benefits; and, (iii) external vulnerabilities arising from currency mismatches in the public sector balance sheet. Interestingly, and according to DIPRES (2006), such a target was more or less in line with the fiscal outcomes recorded during most of the 1990s. In 2008, the target was reduced to a 0.5 percent of GDP surplus because of an improvement in underlying macrofiscal conditions,

\footnotetext{
${ }^{47}$ In 2009-10, the return on accrued financial assets were also adjusted in line with the long-term interest rate.
} 
the reduction in fiscal risks, and the accumulation of financial savings. In 2009, the target was reduced further to balance to accommodate a countercyclical fiscal policy package in the context of the global financial crisis and the sharp reduction in economic activity.

Furthermore, the 2009 target was defined to exclude the impact of temporary tax reduction measures (amounting to about 1 1/2 percent of GDP).

The implementation of the structural balance rule has been supported by two independent panels of experts to determine potential output and the long-term price of copper. Each year, the Finance Ministry assembles two independent panels of 11-15 individuals who are widely regarded as experts in their fields. The Finance Ministry asks the copper price panel to provide a ten-year forecast of copper prices and the reference price is then set as the arithmetic average of the forecasts (excluding two most extreme estimates). From the potential output panel, the ministry requests 5-6 year growth forecasts for: (i) labor force: (ii) real investment; and (iii) total factor productivity. Officials have to date computed average forecasts and use HP-filtered series to estimate trend GDP and the output gap from an aggregate Cobb-Douglas production function. More recently, GDP elasticities disaggregated for 5 types of taxes have been used to derive the structural nonmining revenue.

The structural balance rule framework in Chile has been a critical cornerstone for Chile's strong fiscal performance during the recent economic cycle. In particular, the use of long-term copper prices limited the impact of highly volatile copper prices during the boom years (prices quadrupled between 2003 and 2008) and in 2009 (a 25 percent fall in prices). In fact, the long-term copper price was more or less equivalent to averaging copper prices for rolling 10 -year periods (with a correlation

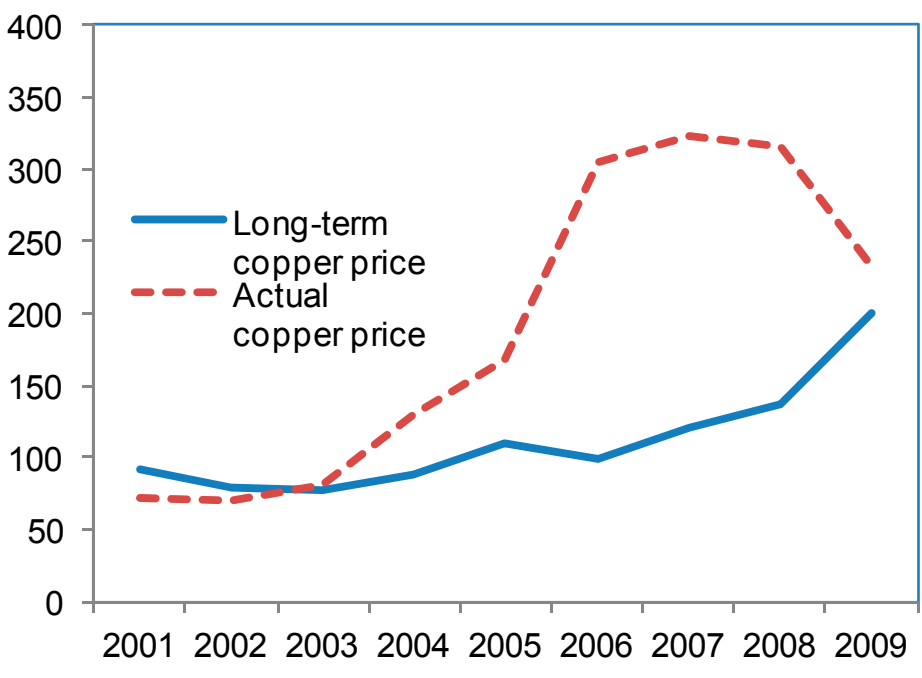
of 0.92 between 2003 and 2009). Primary expenditure in real terms grew by an average of $7 \frac{1}{2}$ percent in 2004-08, highly correlated to the increase in copper prices but still relatively limited. By contrast, primary expenditure in real terms grew by 18 percent in the recessionary year of 2009 thanks to a drawdown of part of the large financial assets previously accrued in the Social and Economic Stabilization Fund.

The success of the rule can be explained in part by the existence of a strong institutional framework, which includes a concentration of fiscal powers in the executive, and an effective inflation-targeting framework. At the same time, issues surrounding the implementation of the rule in 2009-10, such as the ad-hoc exclusion of temporary tax reductions from the target, have brought to the fore some challenges in its functioning. The framework might have become unduly complex over time (with reduced transparency) and rigid. In this context, in May 2010 the authorities established an advisory committee tasked with reviewing the workings of the framework, suggesting ways to improve and simplify its methodologies, and 
increasing its transparency and accountability. A first report by the committee, which was aimed at providing temporary recommendations to guide the formulation of the 2011 budget, suggested changes in the use of inputs from the potential output independent panel, not to exclude temporary tax reductions from the calculation of the structural target, to eliminate the cyclical correction on the return on accrued financial assets, and to revert some accounting practices that were understating the headline and structural deficits. The final report of the committee is expected to provide broader advice on the fiscal rule that would be put in place starting in 2012.

\section{Ecuador (fiscal rules and oil funds)}

Dependence on oil revenues in a context of lack of political consensus and institutional weaknesses has complicated fiscal policy in Ecuador. The country has suffered from recurrent problems in reaching sustainable agreements regarding fiscal policy. This is reflected in the introduction of frequent legal reforms, some short-lived, in the fiscal framework. An important factor behind this instability is lack of trust among various groups involved in the fiscal policy process, which is also reflected in extensive revenue earmarking and budget rigidities. The high degree of budget rigidity, in turn, generated frequent liquidity problems and contributed to the procyclicality of fiscal policy.

In 2000, shortly after dollarization, an oil stabilization fund (FEP) was created. The fund was to receive 45 percent of all oil revenue in excess of oil revenue projected in the budget. The remainder was earmarked to regional projects and some investments. In subsequent years, the FEP accumulated limited resources, and did not seem to have any noticeable impact on the conduct of fiscal policy.

An important attempt to strengthen the fiscal framework and provide greater clarity in the conduct of fiscal policy was made in 2002. That year, a Fiscal Responsibility and Transparency Law (FRTL) were adopted. The law included numerical fiscal rules for the central government, procedural budgetary rules, and the creation of a new oil fund (FEIREP). There were three fiscal rules: a limit on the annual growth of primary expenditure in real terms ( 3.5 percent); a requirement to reduce the nonoil fiscal deficit by at least 0.2 percentage points of GDP a year down to zero; and a requirement to steadily reduce the public debt ratio until it reached at most 40 percent of GDP. The new oil fund was to receive all the oil revenue arising from the operation of the new heavy crude pipeline (OCP). Its resources were earmarked to debt reduction in excess of regularly scheduled amortization (70 percent); stabilization of the budget and to cover expenditures arising from natural disasters and economic emergencies (20 percent); and health and education spending (which was included in the 3.5 percent spending rule; 10 percent).

As oil revenues increased, governments had growing difficulties in withstanding pressures for more public spending and resisting questionable policy initiatives from powerful interest groups and local governments. Thus, as financing constraints lifted, revenues increased, and spending pressures mounted, the implementation of some of the fiscal rules deteriorated over time. Furthermore, the 3.5 percent cap on the growth of primary spending in real terms in the presence of extensive revenue earmarking was bound to reduce even further the already limited fiscal flexibility of the central government. The latter steadily deteriorated over time as revenue-sharing transfers and other revenue earmarking increasingly squeezed out 
discretionary spending. To avoid this effect, it would have been essential to reduce earmarking significantly. However, attempts to pass fiscal reforms through congress, including reductions in earmarking, proved unsuccessful.

The situation was not helped by the existence of certain ambiguities in the FRTL. Notably, the legislation did not specify whether the basis for comparison for the spending and deficit rules was to be the approved budget or the executed budget of the previous fiscal year. This generated incentives to use the most convenient definition depending on the circumstances and still, the nonoil deficit reduction rule was frequently not observed. Invoking economic emergencies also became common, to allow the use of FEIREP resources to increase spending. In addition, the central government resorted to placing debt domestically that was later "bought-back" through FEIREP (as a creative asset-liability management approach). In the event, FEIREP only managed to accumulate limited balances.

The fiscal policy framework was changed and weakened in 2005. Congress approved a reform to the FRTL, sponsored by a new government, that removed capital spending from the spending rule, eliminated the FEIREP oil fund and brought all oil revenues into the budget, and increased the earmarking of oil revenues, thus exacerbating budget rigidities.

Further changes were introduced in 2008. The Constitutional Assembly abolished all existing oil funds and fiscal rules, which were replaced by a new rule. The rule stipulates that current spending can only be financed by nonoil revenue (a sort of "nonoil golden rule"). Arguably, these changes were simply the final result of a gradual and sustained weakening of political support to the fiscal rule and oil funds. The new nonoil golden rule seems to have provided incentives for creative accounting and reclassification of spending. In 2008, recorded capital spending more than doubled.

To summarize, the success of fiscal rules and oil funds in Ecuador was very limited. Rules and the operating mechanisms of funds were repeatedly changed or simply ignored. The fiscal rules did not withstand strong spending pressures during the boom. The oil funds became largely additional earmarking mechanisms that increased budget rigidities and complicated fiscal management.

\section{Mexico (fiscal rule and oil funds)}

Mexico implemented an oil stabilization fund in 2000. A part of government revenues in excess of budgeted amounts was to be transferred to the fund. At first, fund resources could only be used if oil export revenues fell by more than US $\$ 1.5$ a barrel below the reference oil price in the budget. In 2002, however, the rules were changed to allow for full compensation of shortfalls. During that year the fund's accumulated resources were fully drawn.

Major changes in the fiscal framework were introduced in 2006 with the adoption of the Federal Budget and Fiscal Responsibility Law. The law established a fiscal balance target, mechanisms for budgeting under oil price uncertainty, a system of oil funds, and a mediumterm expenditure framework.

A Balanced Budget Rule applies to the budgetary federal public sector, which consists of the federal government, the social security systems, and some public enterprises including 
PEMEX, the national oil company. Under the rule, budgets must target a zero balance on a cash basis. In exceptional circumstances a weaker budget may be proposed, but this requires explicit justification and plans for returning to zero balance. The law requires the government to present the annual budget in the context of a medium-term framework with projections covering the subsequent five years.

Federal oil revenues for each annual budget are projected using a reference oil price. The price is set by a formula, with a weight of $3 / 4$ being given to oil futures prices and a weight of $1 / 4$ to the average oil price of the last ten years. Any excess revenue that results from oil prices being higher than the reference price may first be used to compensate for certain specified budget overruns. The remainder is split between three first tier oil funds ( 90 percent) and state-level investments (10 percent). The first tier oil funds are a stabilization fund and funds to finance PEMEX investment and investment by federal entities. If actual oil revenues turn out to be lower than budgeted due to lower oil prices or exchange rate effects, the oil stabilization funds may make transfers to cover the shortfalls. Until 2010, once the first tier funds reached their statutory ceilings (totaling about $1 \frac{1}{2}$ percent of GDP), any subsequent excesses were to be allocated to a second tier of funds that finance investment by subnational governments (50 percent), PEMEX investment ( 25 percent), and a fund to finance future costs of pension reform ( 25 percent). Resources held at the first-tier funds at end-2009 were equivalent to 1 percent of GDP.

Important developments concerning the fiscal framework took place in 2009-10, at a time when the Mexican economy was hit by a substantial external shock, reflecting in particular the strong real and financial linkages with the U.S. First, beginning in 2009 investment by PEMEX was excluded from the calculation of the budget balance under the fiscal rule; this created room for a discretionary increase in spending. Second, the exceptional circumstances clause in the fiscal rule that allows a temporary widening of the deficit was invoked in the 2010 budget, with the deep recession and associated drop in revenues cited as the basis for the exception; a deficit of $1 / 2$ percent of GDP in the balance targeted by the rule was budgeted. Third, the statutory caps on the resources held in the first tier oil funds - a key source of procyclicality - were suspended for 2010, allowing additional room for saving windfall revenues.

Arguably, the balanced budget rule helped build credibility and contain fiscal deficits in recent years. In particular, it may have had disciplining effects on the legislature, where in the past there had been a tendency to increase spending allocations compared to the proposed budgets.

This said, a higher level of savings of windfall oil revenues during the years prior to the crisis would have facilitated stronger fiscal support to domestic demand during the global financial crisis. ${ }^{48}$ And the fiscal rule proved too constraining in 2009-10 in that compliance with the rule would have entailed a large withdrawal of fiscal stimulus. In the event, the fiscal rule was eased through the mechanisms discussed above.

\footnotetext{
${ }^{48}$ The operation of an oil export revenue hedge mechanism (a put option) protected government finances against downside price risks.
} 
Importantly, a fiscal rule that targets the overall budget balance combined with the presence of significant oil revenues is procyclical, and so it has been in Mexico. Following the introduction of the rule, the rate of growth of spending increased and the NRPB deteriorated, at a time when savings in the oil funds were capped. And changes to the rule in 2009 and the suspension of the rule in 2010 were needed to avoid having to implement an unwarranted procyclical tightening in the midst of a deep recession.

\section{Peru (fiscal rule)}

In the late 1990s, and on the back of a sharp deterioration of the public finances in 1998-99, a growing consensus emerged in Peru towards a formal strengthening of the fiscal framework, including through the adoption of numerical fiscal rules. One of the main motivations for this development was the desire to put the public debt on a firmly downward path.

In 1999 a Fiscal Responsibility and Transparency Law (FRTL) was adopted, as a device to promote fiscal discipline and enhance fiscal transparency. The FRTL was partially modified with the introduction of the Fiscal Management Responsibility Law in 2003 and further changes were introduced in 2007 . The legislation included procedural and fiscal transparency provisions, the requirement to prepare a multi-year macroeconomic and fiscal framework with rolling three-year fiscal projections, and numerical fiscal rules. The original FRTL fiscal rules targeted the deficit of the nonfinancial public sector, the rate of growth of general government expenditure (i.e., including local governments) in real terms; and debt ceilings for the local governments.

The deficit ceilings for 2000-02 featured a declining path for the deficit, from 2 percent of GDP in 2000 to 1 percent of GDP in 2002 and thereafter. Following repeated breaches, the target was loosened in 2003, when a new sliding scale for the deficit was put in place, from 2 percent of GDP in 2003 to 1 percent of GDP in 2005 and thereafter. The limit to the annual growth of expenditure in real terms was loosened in 2003 from 2 percent to 3 percent. The coverage of expenditure under the rule was narrowed in 2007 to consumption of the central government (wages and salaries, goods and services, and pensions) — thus, investment spending and expenditure of the local governments were excluded from the spending rule. The limit on the rate of growth of current spending was also loosened to 4 percent. In addition, in 2008 Congress approved legislation exempting the ministry of health from the current expenditure limits in 2008.

Compliance with the deficit limits proved problematic in the early years (2000-02), but improved significantly in later years as mineral and other revenues boomed, and the limits were met with growing margins until 2008. On the other hand, compliance with the general government expenditure limits proved challenging in the context of the revenue boom despite the loosening of the limit in 2003. This, plus the lack of effective control of subnational spending, led to the narrowing of coverage in 2007 and the increase in the permitted rate of expenditure growth. This said, the expenditure rule, while undergoing several modifications, seems to have provided more of a binding constraint than the deficit rule.

The global financial crisis put pressure on the fiscal rules. The government's policy response included a significant countercyclical fiscal stimulus, which was facilitated by the savings 
accumulated during the boom (Rial, 2010). To accommodate this policy response, recourse was made to an exceptional escape clause in the FRTL that allowed for a temporary relaxation of the ceilings with congressional approval. Thus, a relaxation of the FRTL was approved in May 2009 to allow for a deficit of 2 percent of GDP in 2009-10 (returning to the 1 percent limit in 2011) and a relaxation of the expenditure rule.

\section{Trinidad and Tobago (oil fund)}

In 2000 Trinidad and Tobago's government established an oil fund, the Interim Revenue Stabilization Fund (IRSF), with the aims of promoting fiscal discipline during oil booms, cushioning the effects of unexpected drops in oil prices, and promoting public saving. The fund was not formally approved by parliament, and after an initial transfer, remained inactive for a few years before receiving further transfers. Under the IRSF's rules, deposits into (withdrawals from) the fund were to be made when quarterly oil revenues exceeded (fell short of) the quarterly revenues projected in the budget by at least 10 percent. Budget revenues were based on a discretionary reference price. Deposits were to be at least $2 / 3$ of the difference between projected and actual revenues.

In May 2007 the IRSF was replaced by the Heritage and Stabilization Fund (HSF). The new fund's initial capital comprised the resources accumulated in the IRSF, which were transferred to the HSF. The HSF has stabilization and savings objectives. The stabilization objective is to cushion the impact on spending of petroleum revenue downturns. As regards saving, the fund aims at accumulating assets over time to generate an alternative income stream to support public spending after petroleum revenue declines and oil and gas resources are depleted.

Under the HSF's rules, at least 60 percent of oil and gas revenues in excess of budgeted amounts are to be deposited in the HSF, provided the excess is more than 10 percent of budgeted revenues. Withdrawals from the HSF are permitted in cases where actual oil and gas revenues fall at least 10 percent below budgeted revenues. The withdrawal can be up to 60 percent of the shortfall, but not exceeding 25 percent of the resources in the HSF. Budgeted revenue is estimated on the basis of a reference oil price derived from an 11-year moving average of prices (the 5 years prior to the current fiscal year, and projected prices for the current year and for the next 5 years).

Despite the operation of the IRSF and the HSF, fiscal policy in Trinidad and Tobago was highly procyclical during the boom, with expenditures being increased massively over the period.

\section{Venezuela (fiscal rules and oil funds)}

Venezuela' history with oil funds goes back a long way. In the mid 1970s following the first oil price boom, the Venezuelan Investment Fund (FIV) was created. The objective of the fund was to help save a significant share of the oil windfall. In the event, part of the fund's resources was soon diverted to financing domestic investments and taking equity in public enterprises that subsequently turned out to be loss makers. Thus, while Venezuela's oil exports surged from US\$3 billion in 1972 to US\$20 billion in 1981, during the period the FIV saved only US\$2.5 billion at the central bank. In the 1990s, some of the fund's 
remaining resources were used to support loss-making state companies in the electricity sector - in effect, energy subsidies were provided off budget through the use of the FIV's resources.

Between 1998 and 2000 a new framework to help manage oil resources was put in place. First, an organic budget law was approved in 2000. The law was intended to strengthen fiscal policy and reduce expenditure volatility - a chronic problem in Venezuela. It focused on improving the budget process, including the use of a multiyear framework, and introduced multi-year numerical fiscal rules for the current balance, expenditure growth, and the public debt. Implementation of the law, however, was postponed. Second, an oil stabilization fund, the Macroeconomic Investment and Stabilization Fund (FIEM) was also created. The objectives of the fund were to help insulate the budget and the economy from fluctuations in oil prices. As initially designed in late 1998, contributions to the fund were specified as the oil revenues above a reference value corresponding to a five-year moving average. Resources could only be drawn from the fund in a given year if oil revenues were below the reference value or resources in the fund exceeded 80 percent of the moving average of oil export revenues, in which case resources could be used to amortize public debt.

The rules of the FIEM were substantially modified in 1999. The reference values triggering accumulation or withdrawal of resources were fixed at US\$9 a barrel. Fifty percent of any oil revenues that accrued at a price above this value were to be deposited by the central government, the regional governments and PDVSA (the state oil company) in the FIEM. Discretionary withdrawals from the fund with government authorization and legislative approval were allowed. In 2001 the FIEM was modified again, and the government and PDVSA were exempted from the requirement to make deposits for a while. Many further changes were introduced in subsequent years in the context of the annual budgets.

Over the years, the integration of the oil fund with overall fiscal policy has proved problematic. At times, high-cost borrowing took place to meet the FIEM's rules. Specifically, during periods when the central government was in deficit, the required deposits could only be made in the fund by taking on public debt: the buildup of gross assets in the fund was financed by expensive borrowing. FIEM's rules were frequently changed, ignored, or the operation of the fund was temporarily suspended. And the FIEM did not accumulate any significant resources during 2005-08 when oil prices surged.

More broadly, the organic budget law and the FIEM were put in place with the objective of improving fiscal performance and smoothing expenditure, but they did not achieve this purpose - they did not prevent the implementation of highly procyclical fiscal policies during the oil boom and the subsequent slump. In fact, Clemente, Faris, and Puente (2002), using a general equilibrium model, find that the FIEM seems to have increased macroeconomic volatility. 


\section{APPENDIX II}

\section{Subsidies on Fuel Products and the Fiscal Stance}

The NRPB indicator used in this paper is subject to an important caveat. In several OECs in the sample, fuel products are sold domestically at controlled prices that are often below international prices. Some of these subsidies are explicit (for example, the subsidies on imported products in Bolivia and the negative excise in Mexico). In most of the OECs in the sample, however, some or all the subsidies on fuel products sold domestically are implicit. Often, they are effectively netted against the national oil company's oil revenue, as, for instance, in Ecuador and Venezuela.

In a number of cases there is a lack of reliable time series of fuel subsidies consistent over time. In some countries there have been recurrent changes in the subsidization mechanisms, as well as institutional and fiscal accounting changes. The fiscal accounting treatment of various fuel subsidies also differs across countries.

Therefore, to ensure comparability of treatment among the OECs in the sample, subsidies on fuel products sold domestically, whether implicit or explicit, have not been included in the NRPB. To the extent that domestic fuel prices failed to keep pace with international or import prices during the boom, subsidies increased over time and the fiscal impulse during the upswing would be underestimated by the measured NRPB. For example, in Mexico an excise acts as a tax or a subsidy depending on whether controlled domestic prices of fuels are higher or lower than international prices; the swing between the revenue collected from the excise in 2003 and the subsidy provided in 2008 amounted to about 3 percentage points of GDP. 


\section{APPENDIX III}

\section{What Underlies the Evolution of Nonresource Primary Balances?}

The nonresource fiscal stance in LAC NRECs over the last decade can be explained largely by the trends displayed by primary expenditure, but with significant differences across country groups. In the OECs, the simple average of the ratios of primary spending to NRGDP expanded strongly by about 12 percentage points of NRGDP between 2003 and 2008 , leading to an average 8 percentage point increase in the nonresource primary deficit. Average spending contracted in 2009 as the crisis set in, and the NRPB improved somewhat. In contrast, MECs displayed a more moderate expansion of primary spending until 2008 (with a relatively stable NRPB), but increased primary spending (and the nonresource deficit) strongly in 2009 in response to the global economic crisis.
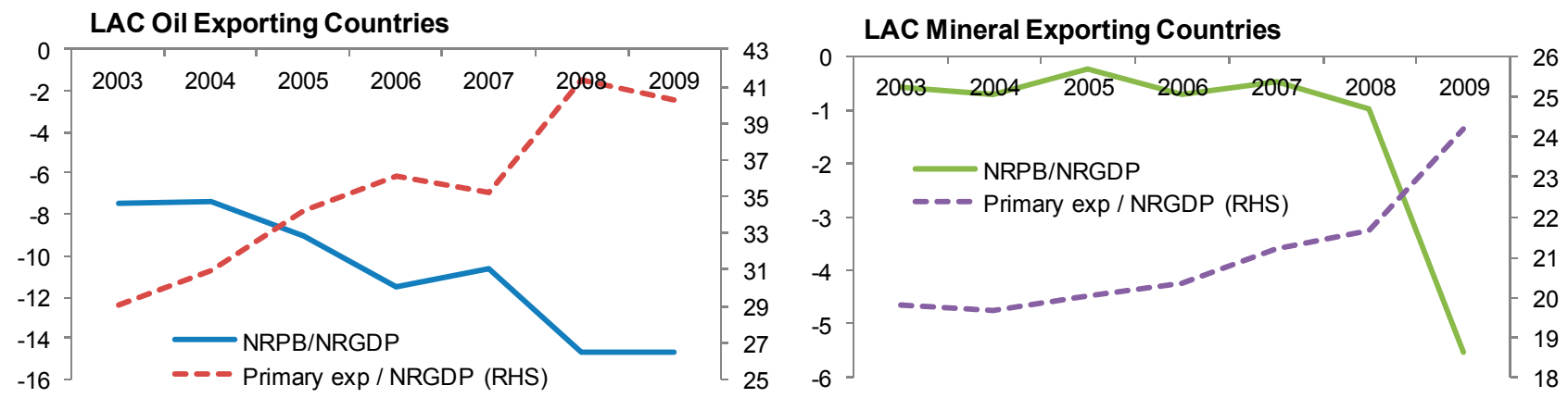

These differing trends can be seen from another angle by looking at the annual rates of increase of expenditure in real terms. On average, primary expenditure in real terms expanded much more rapidly in OECs than in MECs during the boom: 16 percent a year in the former against 8 percent a year in the latter. These figures compare with an average increase of 7 percent in a group of 10 comparator LAC countries (see Footnote 8 in the main text). Within the OECs sample, Venezuela (2004-06) and Ecuador (2007-08) recorded the highest annual expenditure jumps in that period (with maximum rates of increase ranging from 25 to 45 percent). Bolivia and Mexico consistently recorded the more moderate expenditure expansions in their peer groups. In 2009, by contrast, all OECs (with the exception of Mexico) reduced primary expenditure in real terms (quite sharply in the case of Venezuela), while Chile and Peru significantly stepped it up in response to the global economic crisis. In the comparator group of LAC countries, primary expenditure increased in real terms in 2009 at a similar annual rate as

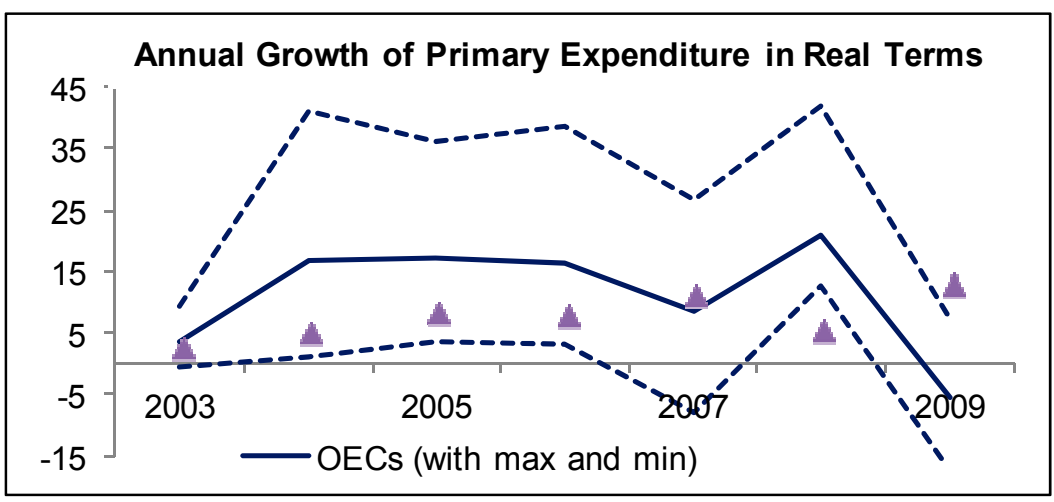
during 2003-08. 


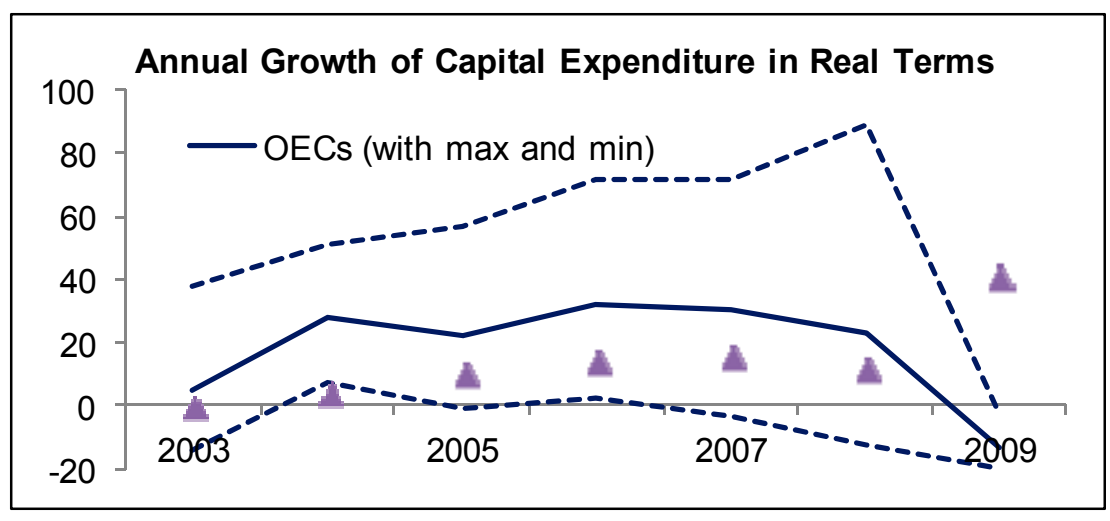

The rates of increase of capital expenditure in real terms were generally larger than those of current spending across the sample until 2008: an average of 27 percent a year in OECs and 12 percent a year in MECs. Trinidad and Tobago (2004-05) and

Ecuador (2007-08) recorded the highest annual expansions in capital spending. The contraction in capital expenditure was quite sharp and generalized in OECs in 2009, while MECs recorded a staggering 40 percent increase in real terms resulting in large part from fiscal stimulus packages. 


\section{APPENDIX IV \\ Calculation of a Long-Term Fiscal Benchmark: An Example}

The calculations of long-term fiscal benchmarks used for the fiscal sustainability analysis in this paper involved the following steps:

- resource wealth (i.e., the present value of future fiscal resource revenue flows) was calculated on the basis of (annual) proven reserves estimates from BP (hydrocarbons) and the U.S. Geological Survey (minerals); constant real resource prices at the level observed in each particular year for which the analysis was carried out; 4-year average government take from resource production; and an interest rate of 3 percent in real terms (the historical average of long-dated U.S. treasury bonds);

- total government wealth was computed as the sum of the resource wealth and net government financial assets;

- the long-term annuity out of the total government wealth was compared to the cyclically adjusted NRPB (i.e., nonresource revenue minus nonresource primary expenditure) as the relevant measure of the consumption out of the government wealth.

The figure below shows a simulation of the long-term sustainability analysis undertaken in this paper, as applied to a representative NREC. The thin line corresponds to resource revenues that are declining in percent of NRGDP until they are exhausted after 20 years. The solid line (annuity) shows the sustainable level of consumption out of the government wealth over 35 (20 plus 15) years. The latter is compared to the horizontal line that shows the continuation into the future of the cyclically-adjusted NRPB as of 2010. The gap between the last two lines suggests that the 2010 fiscal policy stance would be unsustainable from a longterm perspective.

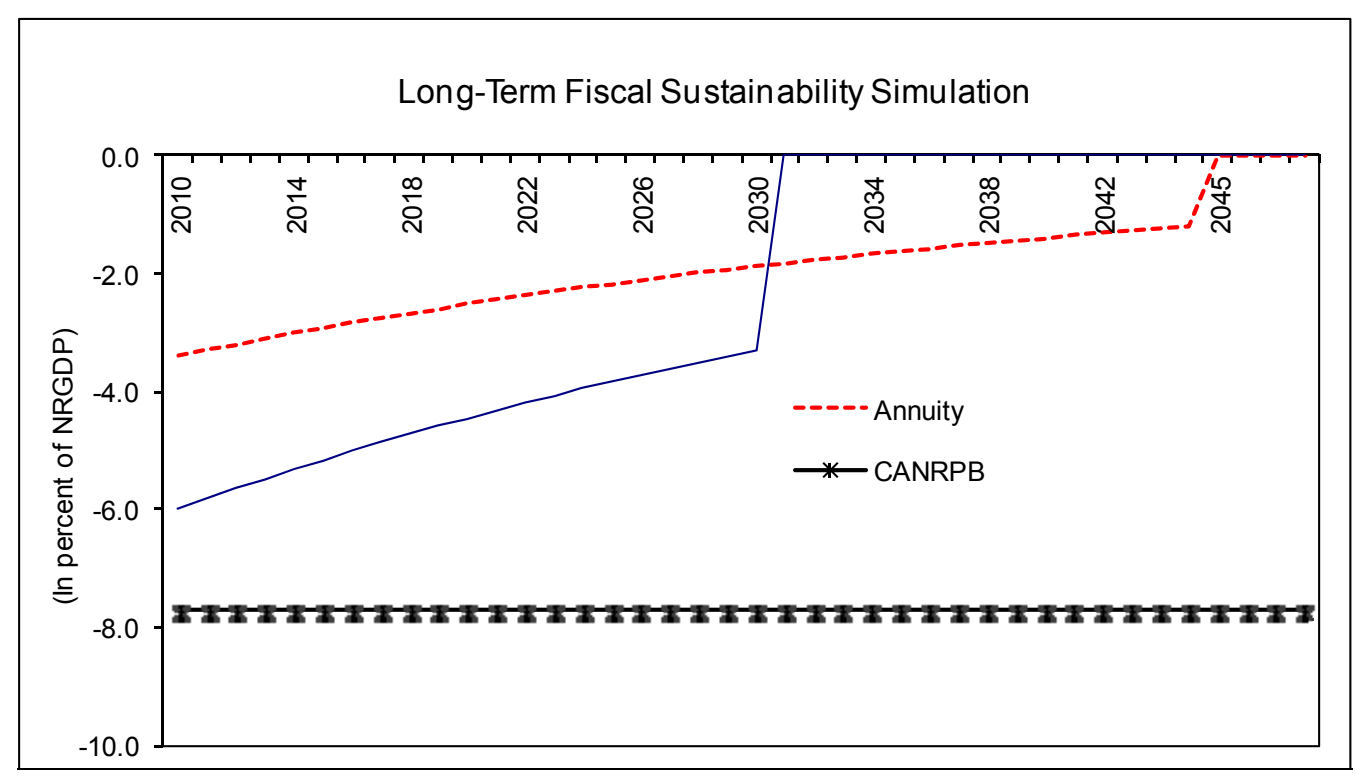

